https://doi.org/10.26749/rstpp.113.53

Papers and Proceedings of the Royal Society of Tasmania, Volume 113, 1979

(ms. received 2.11 .1978$)$

\title{
SOME TASMANIAN SPIDERS OF THE FAMILIES OONOPIDAE, ANAPIDAE AND MYSMENIDAE
}

by V.V. Hickman

Hobart

(with one table and 47 text figures)

\section{ABSTRACT}

HICKIAN, V.V., 1979 (20 vii): Some Tasmanian spiders of the families Donopidae, Anapidae and Mysmenidae. Pap. Proc. R. Soc. Tasm., 113:53-79. ISSN 0080-4703. 69 Cross Street, New Town, Tasmania, Australia.

A key to the Tasmanian Oonopidae is given and six members of the family described. of these four are new species, namely Comifatx insignis, Tasmanoonops futvus, $T$. magnus and $T$. inomatus. The first species is made the type of the new genus Comifalx. It is remarkable for the unusual sexual dimorphism exhibited by the male. The hitherto unknown male of Oonopinus mollipes Hickman is described for the first time. Oonops pulcher Templeton, a well known European oonopid, is recorded from Tasmania for the first time and a brief description of the male given. In the Anapidae two new apneumone species are described and made the types of new genera. The first is Acrobleps hygrophizus, which has a palpless female and spins an orb web. The second is Olgania excavata, which has a deeply indented abdomen and exhibits extensive sclerotization. The family Mysmenidae is recorded from Australia for the first time and is represented by Mysmend tasmaniae sp. $n$. The species is described and an account of its habits and life-history given.

\section{INTRODUCTION}

Some of the spiders described in the present paper form part of a large collection from remote areas in south-western Tasmania. The collection was made during "The Lower Gordon River Scientific Survey" 1976-1978, sponsored by the Hydro-Electric Commission. A debt of gratitude is due to the Commission for providing transport to the areas and for making available at Strathgordon facilities for the preliminary extraction of the material collected.

In the present paper the term "allotype" is applied to a specimen, which is selected as a type and which is opposite in sex to the holotype. The term is used even though the specimen selected may not be a syntype, that is to say, one of the original series collected.

\section{Fami 1 y OONOPIDAE}

The spiders of this family are usually small being about $1.0-2.0 \mathrm{~mm}$ in length. However, some Tasmanian species exceed $5.0 \mathrm{~mm}$. The carapace is without fovea and radial grooves. Six eyes or less are present. The chelicerae lack lateral condyles, the furrow is oblique and the margins usually without teeth. Some species, however, have teeth on one or both margins. The maxillae are converging and have a scopula and serrula. The labium is free. The female pedipalp usually but not always lacks a claw. The legs have an onychium bearing two claws, each with a double row of pectinations. The abdomen has a pair of lung slits in the normal position and, close behind them, a pair of tracheal spiracles, from which tracheae extend into the cephalothorax. A colulus is present in some species, absent in others. 
Most oonopids are found in moss and leaf litter in rain forests, some occur in grass tussocks and a few in buildings. They do not spin a web but some make short tubular retreats. Their egg-sac is plano-convex and made in the retreat.

\section{Key to Tasmanian Oonopidae}

1a. Abdomen above pale grey with a black median mark followed by five black chevrons.................................

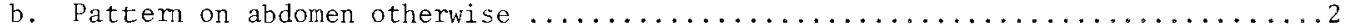

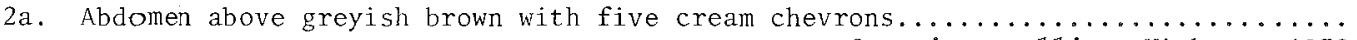

............onopinus molizpes Hickman, 1932

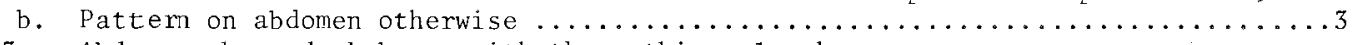

3a. Abdomen above dark brown with three thin pale chevrons $\ldots \ldots \ldots \ldots \ldots \ldots \ldots \ldots$ ....Orchestina Zauncestoniensis Hickman, 1932

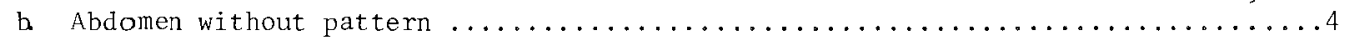

4a. Chelicerae without teeth. Four pairs of spines below first tibiae ........... ............onops puzcher Templeton, 1835

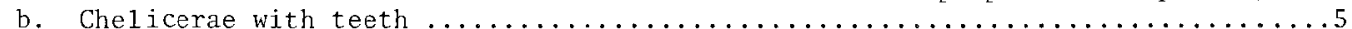

5a. Teeth on both margins of furrow............. Tasmanoonops alipes lickman, 1930

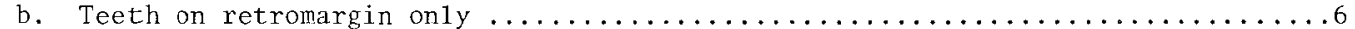

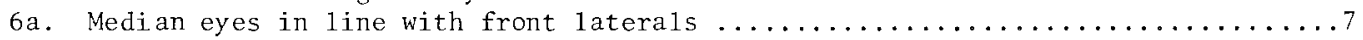

b. Median eyes not in 1 ine with front 1 aterals........... Tasmanoonops fulvus sp. $n$.

7a. Tarsal claws with a double row of 18 teeth. Female with hooked spines on front spinnerets........................ Tasmanoonops inornatus sp. $n$.

b. Tarsal claws with a double row of 12 teeth. Female without hooked spines on front spinnerets......................... Tasmanoonops magnus sp. $n$.

\section{Genus CORNIFALX gen. $\mathrm{n}$.}

\section{Diagnosis}

Anterior margin of carapace of male with a median horn; lateral angles in the form of a rounded lobe. Front of chelicerae in male with a pair of horn-like apophyses. Front of carapace and chelicerae of female normal. Six eyes, median pair contiguous and forming a procurved line with the front laterals. Tarsal claws with a double row of pectinations and a wing-like lobe on the outer side near the base. Six spinnerets, anterior pair vithout hook-shape spines. Colulus present.

Type of genus: Comifalx insignis sp. n.

Comifalx insignis gen. et. sp. n.

Ma1e

$\begin{array}{ll}\text { Measurements in mm:- } & \\ \text { Body length } & 4.66 \\ \text { Carapace length } & 2.31 \\ \text { Carapace width } & 1.62 \\ \text { Abdomen length } & 2.35 \\ \text { Abdomen width } & 1.54\end{array}$

$\begin{array}{ccccccr}\text { Leg } & \text { Femur } & \text { Patella } & \text { Tibia } & \text { Metatarsus } & \text { Tarsus } & \text { Tota1 } \\ 1 & 1.90 & 0.84 & 1.72 & 1.75 & 0.70 & 6.91 \\ 2 & 2.03 & 0.91 & 1.68 & 1.92 & 0.70 & 7.24 \\ 3 & 1.61 & 0.70 & 1.26 & 1.54 & 0.56 & 5.67 \\ 4 & 1.90 & 0.84 & 1.54 & 1.85 & 0.63 & 6.76 \\ \text { Palp } & 0.84 & 0.49 & 0.66 & - & 0.84 & 2.83\end{array}$




\section{V.V. Hickman}

Carapace light brown with darker margin, a transverse dark procurved line with forked ends immediately behind head region. Appendages yellowish brown; femora, patellae and tibiae darker distally and at the sides. Sternum light brown with darker margin. Labium dark on each side. Abdomen pale grey with a median longitudinal black mark on front half of dorsum followed by five black chevrons on hinder half and a dark area on each side of spinnerets (fig. 1).

Carapace oval, narrowed in front to $5 / 8$ its maximum width. Anterior margin with a median horn-like projection extending forwards, lateral angles in the form of rounded lobes. Six eyes, each surrounded by a black rim. Ocular area almost as wide as front of carapace, wider than long in ratio 5:2, and wider behind than in front in ratio $10: 9$. Ratio of eyes $M E: A L E: P L E=11: 13: 15$. ME contiguous, on a transverse line passing between ALE and PLE and separated from ALE by half a diameter and from PLE by twice that distance. Laterals contiguous. Clypeus with a height equal to one diameter of ME.

Chelicerae conical, almost parallel, without lateral condyles, sloping backwards and overhung by clypeus; a large horn-like apophysis projects forwards and upwards from the front of each (fig. 2). Two smaller processes occur near the base of each chelicera and are partly hidden by the overhanging clypeus. Fang well curved. Furrow oblique, two teeth on each margin and a scopula on the promargin. Maxillae almost parallel with serrula on anterior margin and a light scopula on inner angle. Labium wider than long in ratio $11: 10$ and about $4 / 7$ the length of the maxillae, truncate and slightly notched in front, convex from side to side and clothed with few setae. Sternum shield-shape, rebordered, excavated round base of labium, truncate behind, with a sharp marginal point opposite base of each coxa and a smaller point between bases of adjacent coxae, surface convex, polished, with few setae.

Legs in order of length 2.1.4.3. Trichobothria short, arising from small cups that are difficult to see, two on each tibia and one on the distal half of each metatarsus. Tarsi with an onychium bearing two claws, each with a double row of pectinations. On the outer side each claw has a wing-like lobe (fig. 3). The onychium has two long barbed setae near base of claws and a dense clothing of spatulate hairs on ventral surface. Spines are as follows:- First leg 0 . Second leg 0 . Third leg. Femur 0. Patella-prolateral 1-1 on apical half. Tibia- prolatera1 $1-1, \overline{\text { ventral } 1}$ at apex. Metatarsus- dorsal 2 apical, prolateral 1 apical, retrolateral 1 apical, ventral 1 apical. Tarsus 0. Fourth leg. Femur 0. Pate1la 0. Tibia-ventral 2 apical. Metatarsus- dorsal 2 apical, prolatera1 1 apical, retrolateral 1 apical, ventra1 1 apical. Elsewhere 0 .

Palpi without spines. One trichobothrium on tibia. Tarsus long and slender. Genital bulb large, pyriform, with four apophyses (fig. 4).

Abdomen ovoid, clothed with short hair. A pair of lung-slits and a pair of tracheal spiracles in the usual positions near the epigastric furrow. Six spinnerets and a colulus present.

Female

Measurements in $\mathrm{mm}$. Body length

Carapace length 2.35

Carapace width $\quad 1.61$

Abdomen length $\quad 3.36$

Abdomen width $\quad 2.10$ 

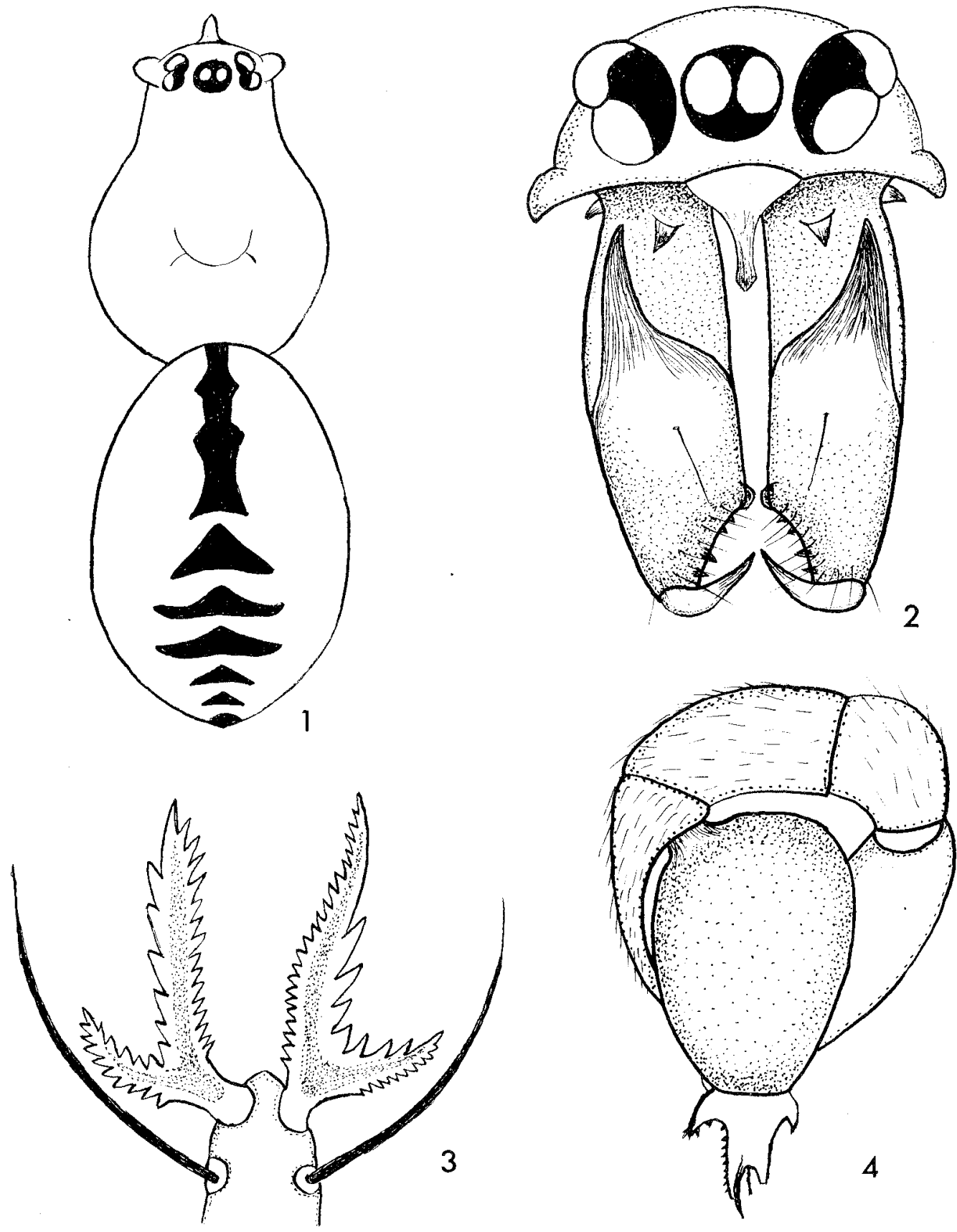

FIGS 1-4.- Comifazx insignis sp. n. Male: 1-dorsal view of body, 2-eyes and chelicerae from front, 3-tarsal claws, 4-left palp. 


$\begin{array}{ccccccr}\text { Leg } & \text { Femur } & \text { Patel1a } & \text { Tibia } & \text { Metatarsus } & \text { Tarsus } & \text { Total } \\ 1 & 2.93 & 0.98 & 1.61 & 1.82 & 0.77 & 8.11 \\ 2 & 2.10 & 0.91 & 1.61 & 1.92 & 0.77 & 7.31 \\ 3 & 1.68 & 0.70 & 1.15 & 1.47 & 0.63 & 5.63 \\ 4 & 2.38 & 0.91 & 1.54 & 1.96 & 0.84 & 7.63 \\ \text { Palp } & 0.70 & 0.49 & 0.49 & - & 0.98 & 2.66\end{array}$

Colour and markings as in male, but in some specimens the posterior cephalic region is darker. Carapace rounded in front without the median horn and lateral lobes of male. Ocular area $4 / 5$ width of carapace in front. Ratio of eyes ME:ALE:PLE = $11: 12: 11$.

Chelicerae conical, vertical, slightly geniculate and constricted at the base but without the horns and basal processes of the male. Two teeth on each side of furrow. Maxillae, labium and sternum as in male. Palpi without claw. Legs in order of length 1.4.2.3. Spines and trichobothria as in male. On ventral side of abdomen there is no distinct epigynum, but a transverse sclerotized bar occurs at the middle of the epigastric furrow in front of the genital aperture. Anterior spinnerets 1 arger than the others and without hook-shaped spines. Colulus conical with a group of about ten setae near apex.

Type locality: Southwestern Tasmania, $145^{\circ} 53^{\prime} \mathrm{E}, 42^{\circ} 38^{\prime} \mathrm{S}, 1$ of (holotype) from Ieaf litter in rain-forest $5 / 1 / 1978$ (L. Hill et al.); $145^{\circ} 46.5^{\prime} \mathrm{E}, 42^{\circ} 31^{\prime} \mathrm{S}, 1$ of (paratype) from moss $9 / 1 / 1978$ (L. Hill et al.); $145^{\circ} 50^{\prime} \mathrm{E}, 42^{\circ} 51^{\prime} \mathrm{S}, 1$ o (allotype) from moss 16/2/1976 (C. Howard et al.) ; $145^{\circ} 46^{\prime} \mathrm{E}, 42^{\circ} 31^{\prime} \mathrm{S}, 3$ oo (paratypes) from leaf litter 19/1/1978 (C. Howard).

Other localities: Western Creek, Tasmania, 1 o from under fallen $\log 31 / 1 / 1930$ (V.,V. Hickman); Betts Vale, Mount Wellington, 1 juvenile from moss 7/7/1960 (V.V. Hickman); various localities in southwestern Tasmania, 10, 7oo, 5 juveniles collected during Jan., Feb. and Mch. 1976/1978 (C. Howard and L. Hil1).

Genus OONOPINUS Simon, 1893

Oonopinus mollipes Hickman, 1932

The original description of this species was based on a female from Launceston, the male being unknown at the time. Some years later two males were found at East Risdon, and the following description is therefore given.

Male

$\begin{array}{ll}\text { Measurements in mm:- } & \\ \text { Body length } & 1.82 \\ \text { Carapace length } & 0.77 \\ \text { Carapace width } & 0.62 \\ \text { Abdomen length } & 1.05 \\ \text { Abdomen width } & 0.67\end{array}$

$\begin{array}{ccccccr}\text { Leg } & \text { Femur } & \text { Pate11a } & \text { Tibia } & \text { Metatarsus } & \text { Tarsus } & \text { Tota1 } \\ 1 & 0.67 & 0.26 & 0.56 & 0.49 & 0.32 & 2.30 \\ 2 & 0.63 & 0.25 & 0.53 & 0.48 & 0.31 & 2.20 \\ 3 & 0.43 & 0.21 & 0.35 & 0.39 & 0.21 & 1.59 \\ 4 & 0.56 & 0.21 & 0.42 & 0.48 & 0.21 & 1.88 \\ \text { Palp } & 0.22 & 0.15 & 0.14 & - & 0.33 & 0.84\end{array}$


Tasmanian Oonopid, Anapid and Mysmenid Spiders
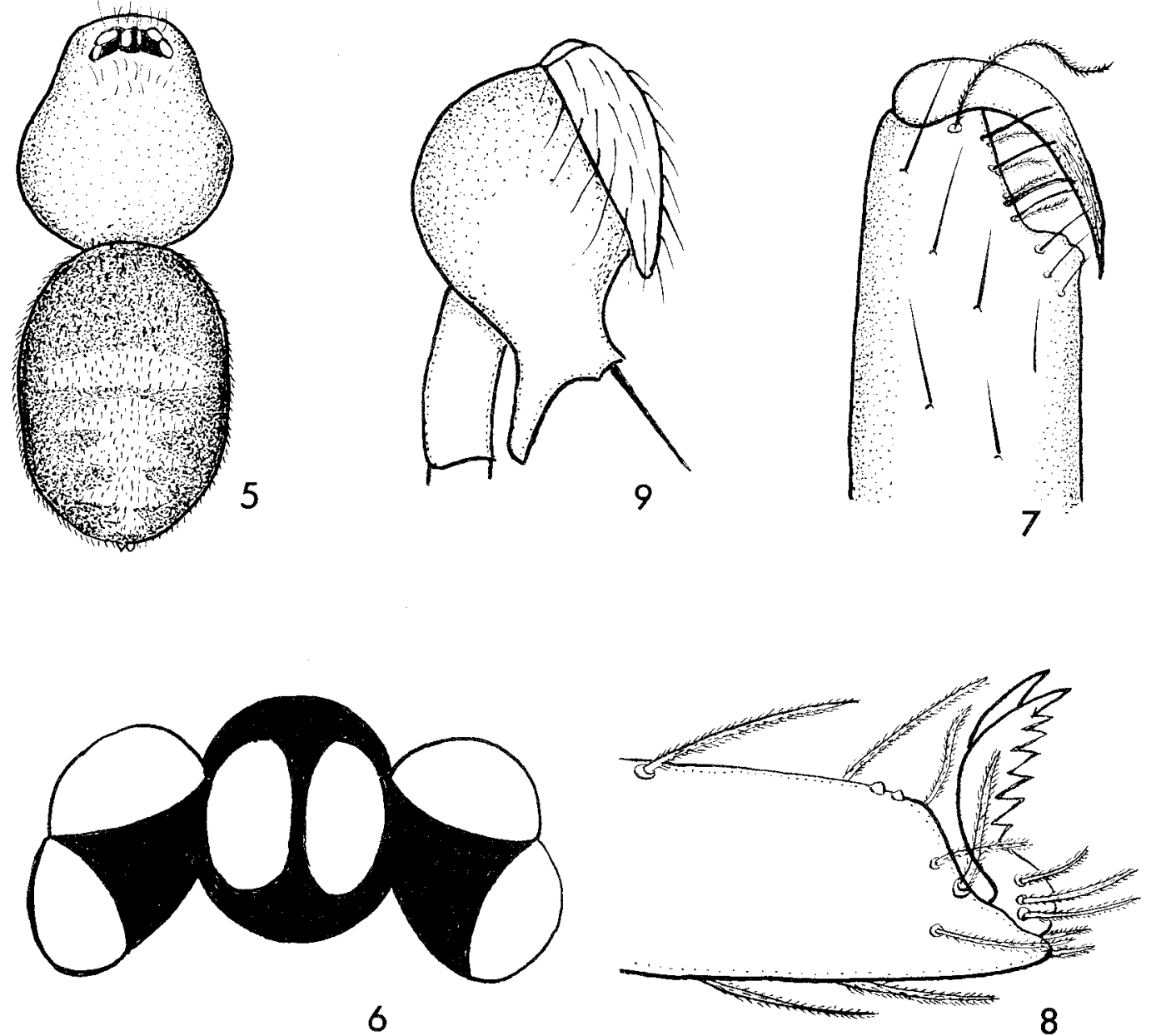

FIGS 5-9.- Oonopinus molzipes Hickman. Male: 5-dorsal view of body, 6-eyes, 7-prolateral side of left chelicera, 8-tarsal claws, 9-right palp.

Cephalothorax dark brown; appendages and sternum 1 ight brown, dorsum of abdomen brownish grey with five cream-coloured chevrons on posterior two thirds (fig. 5), venter pale yellow. Carapace oval, narrowed in front to $5 / 11$ of its maximum width, sides granular, a few barbed hairs in front of and behind ocular area. Six eyes (fig. 6) about equal in size and surrounded by black rings. Ocular area 4/5 the width of the cephalic region in front, and wider than long in ratio 17:9. Median eyes contiguous, almost touching ALE in front, but separated from PLE by $3 / 4$ of their long diameter. Height of clypeus equal to $6 / 5 \mathrm{long}$ diameter of median eyes. Chelicerae 
(fig. 7) conical, vertical, $0.37 \mathrm{~mm}$ long and $0.14 \mathrm{~mm}$ in greatest width, without lateral condyles, surface granular and clothed with a few long hairs; furrow oblique, margins without teeth, basal end with a large tubercle, which is slightly bifid. In front of promargin is a row of about six spinous setae, each accompanied by a barbed hair. At base of fang is a long flagelliform barbed hair. Maxillae narrow, slightly converging, provided with serrula and scopula. Labium triangular, truncated and notched in front, wider than long and about half the length of the maxillae. Sternum broadly oval, convex, truncate behind separating fourth coxae by $3 / 2$ of their width, margin rebordered, laterally the surface is furnished with a few hairs that point inwards.

Legs in order of length 4.1.2.3., clothed with barbed hairs but without spines, two trichobothria on each tibia and one on each metatarsus near apex. Tarsus with a group of small sensory tubercles at distal end; claws carried on an onychium, each with a double row of about six teeth (fig. 8).

Palpi clothed with barbed hairs, two trichobothria on tibiae, spines lacking. Genital bulb large and pyriform; apex widened and forming two projections of unequal length. From the shorter projection a long black spiniform embolus extends (fig. 9).

Abdomen ovoid, nearly twice as long as wide, clothed with barbed hairs. Six spinnerets. Colulus lacking. A pair of lung-slits and a pair of tracheal spiracles in the norma 1 position.

Locality: East Risdon Tasmania, 1 d (allotype), 2 oo from grass tussocks 19/5/1937; 1 ó, 4 oo 23/9/1947 (V.V. Hickman).

Other localities: Liffey Falls, Tasmania, 1 o juvenile from moss 14/5/1953 (V.V. Hickman); southwestern Tasmania, $145^{\circ} 53^{\prime} \mathrm{E}, 42^{\circ} 48^{\prime} \mathrm{S}, 1$ o from moss $1 / 3 / 1977$ (L. Hill et al.).

\section{Genus OONOPS Templeton, 1835}

Oonops pulcher Templeton, 1835

This species is a we11-known European spider with a wide distribution. It has probably been introduced into Tasmania and is here recorded for the first time. The following brief description should enable the species to be identified.

Ma1e

$\begin{array}{ll}\text { Measurements in mm: - } & \\ \text { Body length } & 1.19 \\ \text { Carapace length } & 0.56 \\ \text { Carapace width } & 0.42 \\ \text { Abdomen length } & 0.63 \\ \text { Abdomen width } & 0.32\end{array}$

$\begin{array}{ccccccr}\text { Leg } & \text { Fenur } & \text { Patella } & \text { Tibia } & \text { Metatarsus } & \text { Tarsus } & \text { Total } \\ 1 & 0.53 & 0.22 & 0.47 & 0.36 & 0.25 & 1.83 \\ 2 & 0.55 & 0.23 & 0.53 & 0.47 & 0.25 & 2.03 \\ 3 & 0.42 & 0.21 & 0.34 & 0.34 & 0.18 & 1.49 \\ 4 & 0.60 & 0.24 & 0.52 & 0.47 & 0.23 & 2.06 \\ \text { Palp } & 0.18 & 0.12 & 0.14 & - & 0.12 & 0.56\end{array}$

Colour of body and appendages light red. Carapace wide and convex, highest part slightly behind middle. Six eyes (fig. 10). Ocular area wider than long in ratio 13:8. 


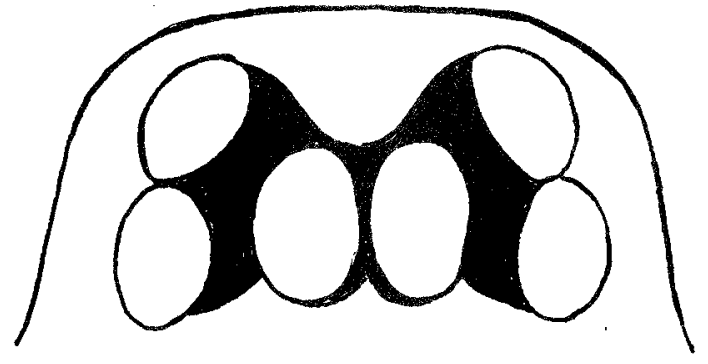

10

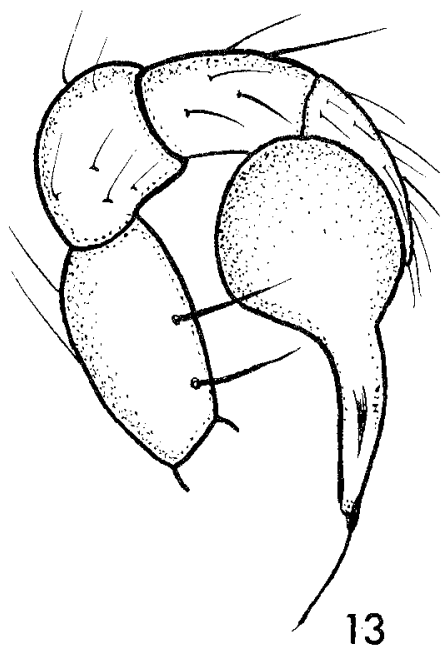

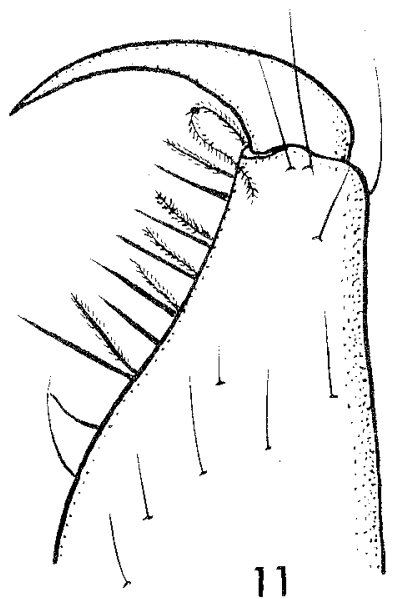

11

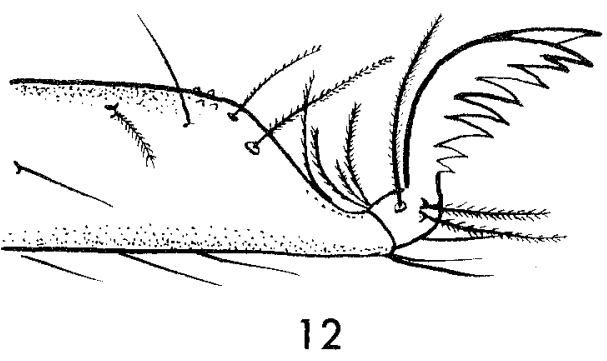

FIGS 10-13.- Oonops pulcher Templeton. Male: 10-eyes, 11-prolateral side of right chelicera, 12-tarsal claws, 13-right palp.

Eyes about equal in size, median pair contiguous, laterals also contiguous. Viewed from above the medians and front laterals form a procurved row. Chelicerae (fig. 11) conica1, vertical, without lateral condyles, furrow oblique and without teeth on both margins. In front of promargin is a row of about seven spine-like setae accompanied by barbed hairs. At base of fang a long flagelliform barbed hair. Maxi1lae converging, with a scopula at apex and along distal half of inner margin, a serrula on apical third of outer margin. Labium wider than long and about half the length of maxillae. Sternum shield-shape, broadly rounded posteriorly and widely 


\section{V.V. Hickman}

separating fourth coxae. Legs in order of length 4.2.1.3., lightly clothed with long hairs; spines present on all tibiae and metatarsi, there being four pairs below first tibiae. Two trichobothria on each tibia and one near apex of each metatarsus. Tarsi with an onychium bearing two claws, each with a double row of about six teeth, those in the outer row being larger than those in the inner row. Two long curved barbed hairs at base of claws and three at base of onychium (fig. 12).

Palpi lightly clothed with long hairs, two erect spines below femur, two trichobothrja on tibia. Genital bulb pyriform, with a long slender process projecting from the apex (fig. 13). Near the base of the process is a group of minute tubercles. At the side of the distal part of the bulb is a stout recumbent spine and to one side of the spine a group of minute thorn-like processes.

Abdomen about twice as long as wide, clothed with barbed hairs. Six spinnerets. Colulus lacking.

Locality: Launceston, Tasmania. 1 f found under a board in a poultry enclosure 29/4/1928 (V.V. Hickman).

Genus TASMANOONOPS Hickman, 1930

Tasmanoonops fulvus sp. n.

Male

$\begin{array}{ll}\text { Measurements in mm:- } & \\ \text { Body length } & 2.03 \\ \text { Carapace length } & 1.03 \\ \text { Carapace width } & 0.74 \\ \text { Abdomen length } & 1.00 \\ \text { Abdomen width, } & 0.56\end{array}$

$\begin{array}{crccccr}\text { Leg } & \text { Femur } & \text { Patella } & \text { Tibia } & \text { Metatarsus } & \text { Tarsus } & \text { Tota1 } \\ 1 & 0.75 & 0.31 & 0.57 & 0.55 & 0.34 & 2.52 \\ 2 & 0.68 & 0.27 & 0.52 & 0.48 & 0.33 & 2.28 \\ 3 & 0.66 & 0.23 & 0.45 & 0.44 & 0.30 & 2.08 \\ 4 & 0.82 & 0.27 & 0.61 & 0.75 & 0.34 & 2.79 \\ \text { Palp } & 0.28 & 0.17 & 0.19 & - & 0.22 & 0.86\end{array}$

Cephalothorax and appendages yellowish brown; abdomen grey without pattern. Carapace oval, narrowed in front to half its maximum width, surface smooth, lateral margins rebordered, a few hairs on cephalic region. Six eyes in a close group (fig. 14), each eye surrounded by a black ring. Ocular area $5 / 6$ of width of carapace in front and twice as wide as long. Eyes about equal in size; median eyes on a transverse line passing between lateral eyes of each side. Chelicerae narrow, conical, vertical, without lateral condyles; furrow oblique with two teeth on retromargin; a row of erect spines accompanied by barbed hairs in front of promargin. Near base of fang is a very long flagelliform barbed hair and also a very long hair near the proximal end of promargin (fig. 15). No teeth on the promargin. Maxillae almost parallel and provided with serrula and scopula. Labium longer than wide, truncate in front and slightly more than half as long as maxillae. Sternum shield-shape, convex, polished, rebordered and ending in a rounded point between the fourth coxae, which are well separated.

Legs in order of length 4.1.2.3. Two trichobothria on each tibia and one on the distal half of each metatarsus. Two tarsal claws, carried on an onychium and with a double row of about seven teeth. Spines as follows:- First leg 0 . Second leg. 0 . 

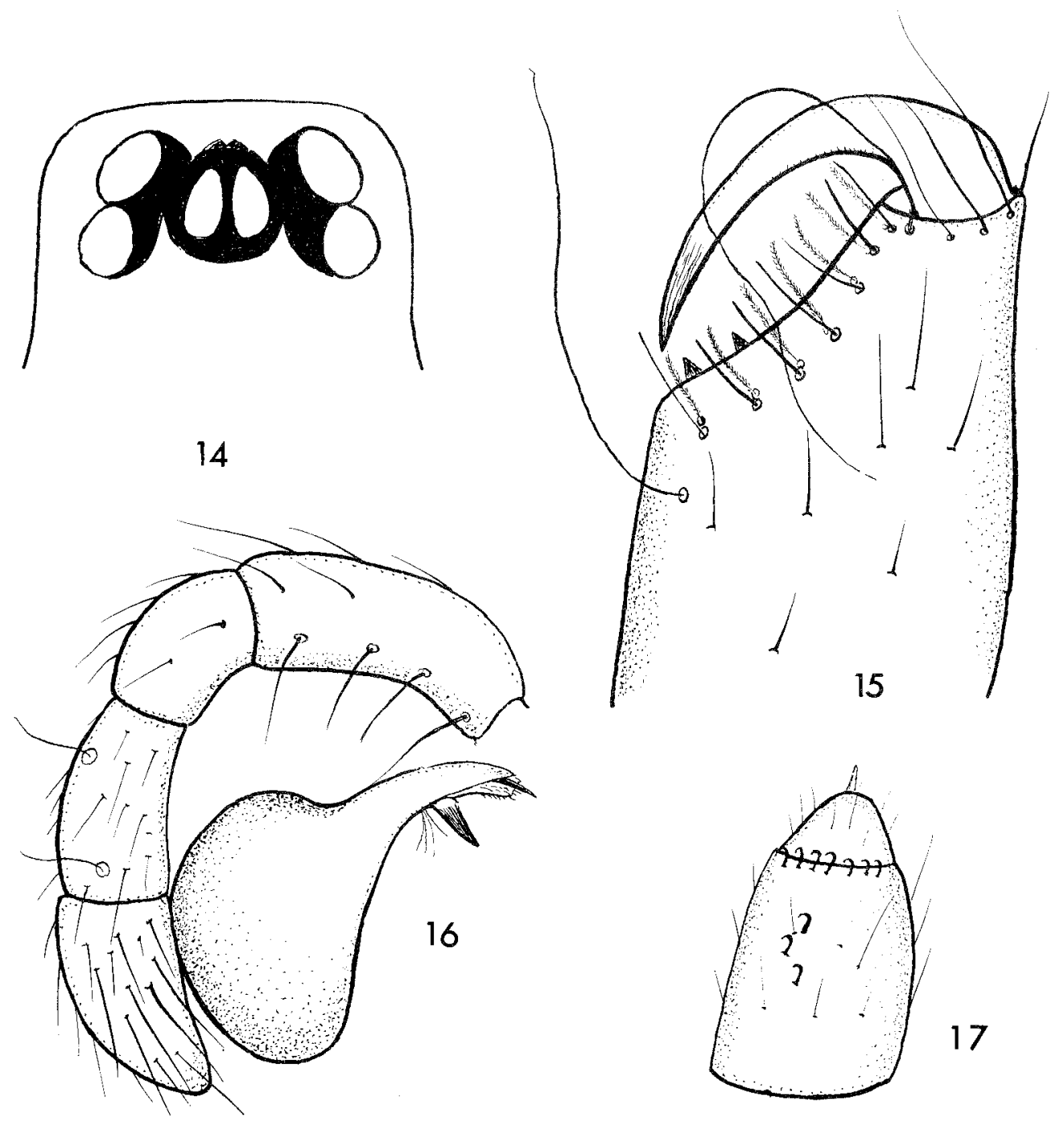

FIGS 14-17.- Tasmanoonops fulous sp. n. Male: 14-eyes, 15-prolateral side of right chelicera, 16-right palp. Female: 17-ventral side of front spinneret.

Third leg. Femur 0, patella 0. Tibia-dorsal 0, prolateral 1-1, retrolatera 1 1-1, ventral 1-2 apical. Metatarsus-dorsal 0, prolateral 1, retrolateral 1, ventral 1-2 apica1. Tarsus 0. Fourth 1eg. Femur 0. Patella 0. Tibia-dorsal 0, prolateral 1-1, retrolateral 1-1-1, ventral 1-1-2 apical. Metatarsus as for tibia. Tarsus 0. 


\section{V.V. Hickman}

Palpi (fig. 16) without spines but with some coarse setae above tibia and tarsus. Two trichobothria on tibia. Genita1 bulb pyriform with a strong tooth-1ike apophysis near distal end. At the base of the apophysis is a group of four setae. The apical part of the bulb encloses a sharp black spine and a small barbed ligule.

Abdomen ovoid, clothed with recumbent hairs. Venter with a pair of lung-slits and a pair of tracheal spiracles in the normal position. Six spinnerets and a colulus present. Colulus furnished with setae.

\section{Female}

$\begin{array}{ll}\text { Measurements in mm:- } & \\ \text { Body length } & 2.46 \\ \text { Carapace length } & 0.99 \\ \text { Carapace width } & 0.77 \\ \text { Abdomen length } & 1.47 \\ \text { Abdomen width } & 0.92\end{array}$

$\begin{array}{ccccccr}\text { Leg } & \text { Femur } & \text { Patella } & \text { Tibia } & \text { Metatarsus } & \text { Tarsus } & \text { Total } \\ 1 & 0.70 & 0.33 & 0.54 & 0.52 & 0.30 & 2.39 \\ 2 & 0.70 & 0.33 & 0.53 & 0.49 & 0.29 & 2.34 \\ 3 & 0.63 & 0.21 & 0.42 & 0.49 & 0.28 & 2.03 \\ 4 & 0.78 & 0.28 & 0.59 & 0.73 & 0.33 & 2.74 \\ \text { Palp } & 0.28 & 0.14 & 0.20 & - & 0.29 & 0.91\end{array}$

Female resembles male in most features. Chelicerae are slightly stouter but have the same dentition. Palpi have two trichobothria on tibia as in male; a claw is absent but the tarsus has a number of coarse barbed setae at the apex. The anterior spinnerets differ from those of the male in having a number of hook-shaped spines on the ventral surface (fig. 17).

Type locality: southwestern Tasmania, $145^{\circ} 50^{\prime} \mathrm{E}, 42^{\circ} 56^{\prime} \mathrm{S}, 1 \mathrm{~d}^{\prime}$ (holotype) from leaf litter $18 / 2 / 1977$ (C. Howard et al.); $145^{\circ} 42^{\circ} \mathrm{E}, 42^{\circ} 35^{\prime} \mathrm{S}, 1_{+}$(allotype) from moss $31 / 1 / 1976$ (C. Howard et az.).

Other 1ocalities: Near southern end of Lake St. Clair, 1 of, 8 oo from moss $7 / 2 / 1945$ (V.V. Hickman); Tarra1eah, 1 d, 1 o from moss 16/4/1959 (V.V. Hickman); South side of Lyell Highway, east King William Saddle 3 ód, 1 o from litter under Nothofagus trees 19/3/1974 (J.L. Hickman); various localities in southwestern Tasmania, 3 o 7 , 7 oo from moss and litter, in rain-forest areas during January and February $1976-1977^{++}$ (C. Howard, L. Hill et al.).

Tasmanoonops inomatus sp. $\mathrm{n}$.

Male

$\begin{array}{ll}\text { Measurements in mm:- } & \\ \text { Body length } & 3.00 \\ \text { Carapace length } & 1.42 \\ \text { Carapace width } & 1.12 \\ \text { Abdomen length } & 1.62 \\ \text { Abdomen width } & 0.87\end{array}$

$\begin{array}{crccccr}\text { Leg } & \text { Femur } & \text { Pate1la } & \text { Tibia } & \text { Metatarsus } & \text { Tarsus } & \text { Total } \\ 1 & 1.50 & 0.62 & 1.25 & 1.30 & 0.55 & 5.22 \\ 2 & 1.47 & 0.52 & 1.27 & 1.28 & 0.52 & 5.06 \\ 3 & 1.25 & 0.52 & 0.98 & 1.10 & 0.50 & 4.35 \\ 4 & 1.62 & 0.55 & 1.05 & 1.60 & 0.55 & 5.37 \\ \text { Palp } & 0.55 & 0.25 & 0.27 & - & 0.50 & 1.57\end{array}$


64
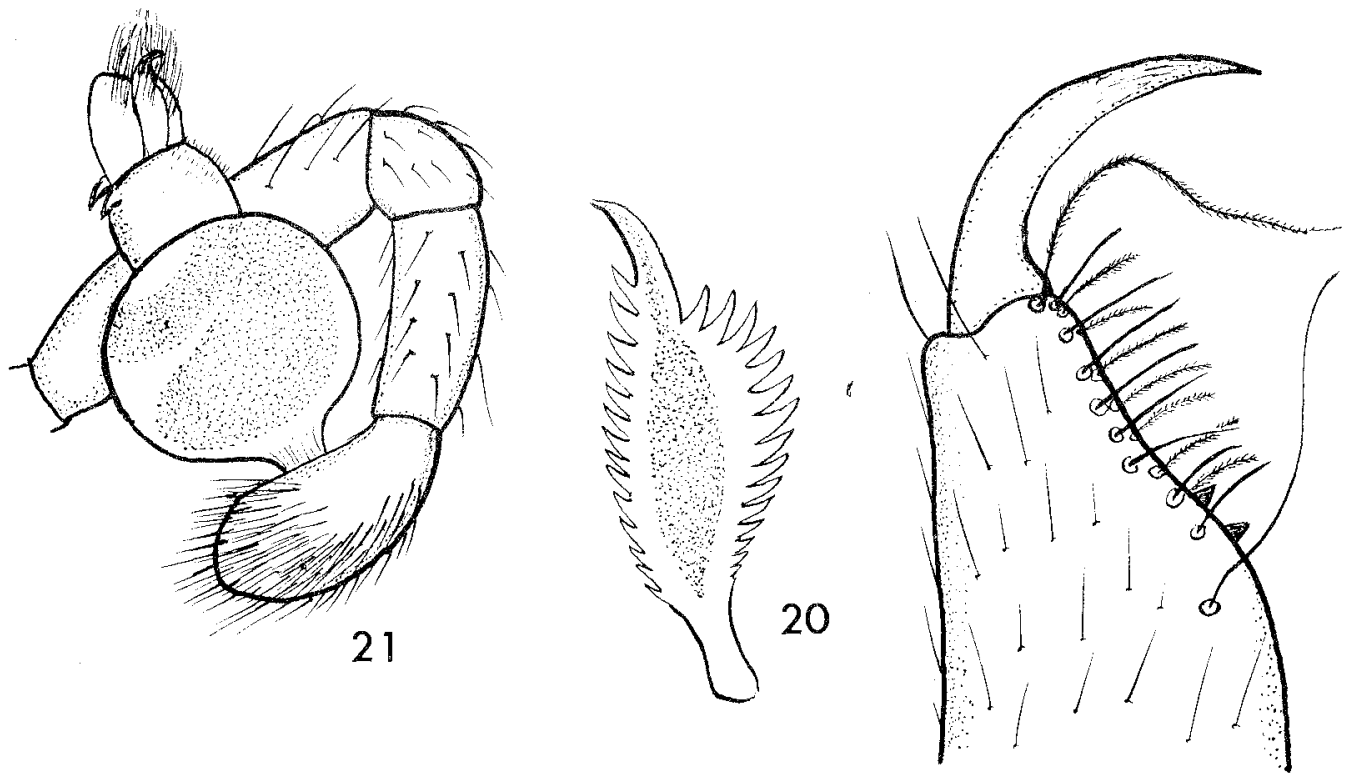

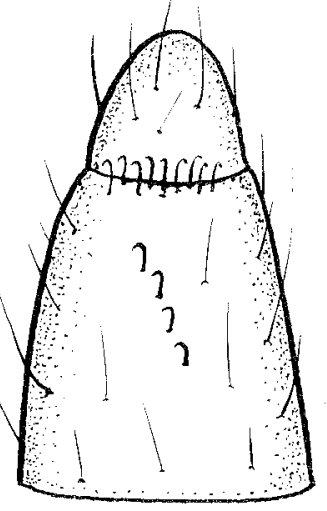

23

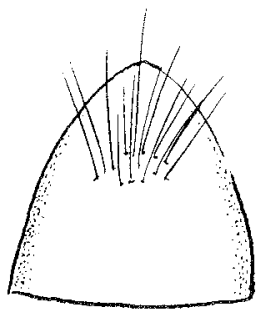

22

19

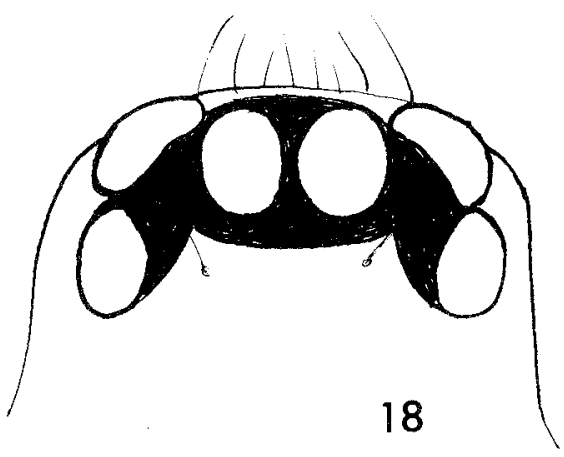

FIGS 18-23.- Tasmanoonops inornatus sp. n. Male: 18-eyes, 19-prolateral side of left chelicera, 20-ventral side of claw, 21-1eft palp, 22-colulus. Female: 23-ventra1 side of front spinneret.

Cephalothorax and appendages brownish yellow; abdomen grey without pattern. Carapace ova1, narrowed in front to $1 / 6$ its greatest width, lateral margins rebordered, surface clothed with fine recumbent hairs, several bristles in a median row on cephalic part. No fovea or radial grooves. Six eyes (fig. 18) of about equal size. Ocular area the full width of front of carapace and twice as wide as long. Viewed 
from above ME in line with AlsE and almost touching ALE in front, but separated from PLE by half their diameter. ALE and PLE contiguous. Height of clypeus equal to half the diameter of ME. About 12 setae in front of eyes. Chelicerae conical, vertical, paralle1, without lateral condyles and three times as long as wide; furrow oblique, two teeth on retromargin, none on promargin. In front of promargin a row of erect spines accompanied by barbed hairs. Near base of fang a very long flagelliform barbed hair and also a long hair near proximal end of furrow (fig. 19). Maxillae almost parallel and provided with scopula and serrula. Labium wider than long and about half the length of maxillae, truncate and notched in front. Sternum shield-shape, convex, truncate in front and pointed behind, rebordered, clothed on each side with a few hairs and on the posterior point with ten larger setae, nargin produced into a sharp point opposite base of each coxa.

Legs in order of length 4.1.2.3.; clothed wi.th short hairs, two trichobothria on each tibia and one near the apex of each metatarsus. A group of three small sensory tubercles near apex of each tarsus. The two tarsal claws are carried on an onychium, each has a double row of about 18 teeth and on the outer side a wing-like lobe (fig. 20). The onychium is provided below with a number of spatulate hairs. Two large barbed setae occur near the base of the claws and three smaller ones in a transverse row at the base of the onychium. Spines are as follows:- First leg 0. Second leg 0. Third leg. Femur 0. Patella 0. Tibia - dorsa1 0, prolatera1 1-1-1, retrolatera1 1-1, ventral 2 apical. Metatarsus - dorsal 0, prolateral 1-1, retrolateral 1-1, ventral 2-1 apical. Tarsus 0. Fourth leg. Femur 0. Patella 0. Tibia - dorsal 0, pro-

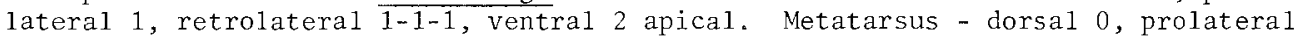
1-1-1-1, retrolateral 1-1, ventral 1 apical. Tarsus 0.

Palpi (fig. 21) lightly clothed with hairs but more densely on tarsus than elsewhere. Two trichobothria on tibia. Spines absent. Genital bulb pyriform but constricted to form a large globular basal division and a smaller apical part. The latter is partly clothed with very short hairs. At the distal end is a wide ligule densely covered with fine hairs; at the front of the ligule a spine-like process with a hook-shaped end. On the other side of the distal end are two thorn-like projections.

Abdomen ovoid, almost twice as long as wide, clothed with short hairs, a pair of lung-slits and a pair of tracheal spiracles in the usual position on the venter. Six spinnerets and a colulus present, the colulus with about ten setae (fig. 22).

Female

$\begin{array}{ll}\text { Measurements in mun:- } & \\ \text { Body length } & 2.66 \\ \text { Carapace length } & 1.12 \\ \text { Caparace width } & 0.70 \\ \text { Abdomen length } & 1.54 \\ \text { Abdomen width } & 0.84\end{array}$

$\begin{array}{crccccr}\text { Leg } & \text { Femur } & \text { Patella } & \text { Tibia } & \text { Metatarsus } & \text { Tarsus } & \text { Total } \\ 1 & 0.82 & 0.41 & 0.62 & 0.62 & 0.37 & 2.84 \\ 2 & 0.81 & 0.41 & 0.59 & 0.60 & 0.37 & 2.78 \\ 3 & 0.55 & 0.34 & 0.44 & 0.53 & 0.30 & 2.16 \\ 4 & 0.89 & 0.40 & 0.70 & 0.78 & 0.34 & 3.11 \\ \text { Palp } & 0.30 & 0.20 & 0.19 & - & 0.34 & 1.03\end{array}$

Female resembles the male in colour and general features. Palpi lack a claw, but the tarsus ends in a sharp point, coarse spine-like setae and barbed hairs. Anterior spinnerets with a number of hook-shaped spines on the ventral surface and some forming a double row at the distal end of the first segment (fig. 23). Colulus as in male. 
Type locality: Southwestern Tasmania, $145^{\circ} 53^{\prime} \mathrm{E}, 42^{\circ} 48^{\prime} \mathrm{s}, 1$ ó (holotype) from leaf litter 1/3/1977 (L. Hi11 et aZ.); $145^{\circ} 45.5^{\prime} \mathrm{E}, 42^{\circ} 31^{\prime} \mathrm{S}, 1^{\circ}$ o (a1lotype) from leaf litter 19/1/1978; $145^{\circ} 42^{\prime} \mathrm{E}, 42^{\circ} 35^{\prime} \mathrm{S}, 1$ of (paratype) from moss $31 / 1 / 1976$ and 1 o (paratype) from leaf litter $29 / 1 / 1976 ; 145^{\circ} 43^{\prime} \mathrm{E}, 42^{\circ} 34^{\prime} \mathrm{S}, 1$ o (paratype) from ${ }^{+}$ leaf litter 2/2/1976 (C. Howard et al.).

Tasmanoonops magnus sp. n.

Male

$\begin{array}{ll}\text { Measurements in mm:- } & \\ \text { Body length } & 4.17 \\ \text { Carapace length } & 1.82 \\ \text { Carapace width } & 1.37 \\ \text { Abdomen length } & 2.34 \\ \text { Abdomen width } & 1.26\end{array}$

$\begin{array}{crccccr}\text { Leg } & \text { Femur } & \text { Patella } & \text { Tibia } & \text { Metatarsus } & \text { Tarsus } & \text { Total } \\ 1 & 2.00 & 0.86 & 1.83 & 1.94 & 0.80 & 7.43 \\ 2 & 2.17 & 0.86 & 1.88 & 2.00 & 0.80 & 7.71 \\ 3 & 1.77 & 0.63 & 1.31 & 1.60 & 0.57 & 5.88 \\ 4 & 2.28 & 0.68 & 1.88 & 2.17 & 0.63 & 7.64 \\ \text { Palp } & 0.57 & 0.34 & 0.40 & - & 0.46 & 1.77\end{array}$

Cephalothorax and appendages light brown, sternum darker round the margin. Abdomen brownish grey. Carapace oval, convex, narrowed in front to half its maximum width, lightly clothed with short recumbent hairs pointing forward, no fovea or radia1 grooves. Six eyes (fig. 24). Ocular area as wide as front of cephalic part and twice as wide as long. Eyes about equal in size. Viewed from above ME in line with ALE. ME contiguous, separated from ALE by 5/7 and from PLE by $9 / 7$ of their diameter.

Lateral eyes contiguous. All eyes surrounded by black rings. Chelicerae $0.86 \mathrm{~mm}$ long and $0.20 \mathrm{~mm}$ wide, vertical, without lateral condyles, furrow oblique, retromargin with two teeth, promargin without teeth (fig. 25). In front of promargin a row of about eleven spine-like setae, most of them accompanied by a barbed hair. At distal end of row near base of fang a long flagelliform barbed seta and a second long seta near the proximal end of row. Maxillae almost parallel with a tuft of long hairs at apex and a scopula along inner margin; a serrula is present on antero-lateral side. Labium wider than long, slightly more than half the length of maxillae, convex from side to side, widely truncate in front. Sternum shield shape, convex, excavated round bases of labium and maxillae, pointed behind, margin rebordered and with a large point opposite base of each coxa, a smaller point between bases of adjacent coxae.

Legs in order of length 4.2.1.3. First and second legs almost equal in length. Two trichobothria on each tibia and one near the apex of each metatarsus. Tarsus with an onychium bearing two claws, each with a double row of about twelve teeth and a winglike lobe on the outer side. Onychium with a large number of spatulate hair below and a Iong barbed seta on each side near base of claws. Near the apex of tarsus at the base of a long seta are two sensory tubercles (fig. 26). Spines as follows:- First leg 0. Second leg 0. Third leg. Femur 0. Patella 0. Tibia - dorsal 0, prolateral 1-1-1, retrolateral 0 , ventral 1. Metatarsus - dorsal 0, prolateral 1 apical, retrolatera1 0, ventral 1 apical. Tarsus 0. Fourth leg. Femur 0. Patella 0. Tibia dorsal 0, prolateral 1 apical, ventral 0 . Metatarsus - dorsal 0, prolateral 1-1-1, retrolateral 1-1-1, ventral 0-1-1. Tarsus 0.

Palpi (fig. 27) without spines, distal half of tarsus densely clothed with hairs, two trichobothria on tibia. Genital bulb pyriform with a slight constriction dividing it into a Iarge basal part and a small apical part. A short spine-like structure 
V.V. Hickman
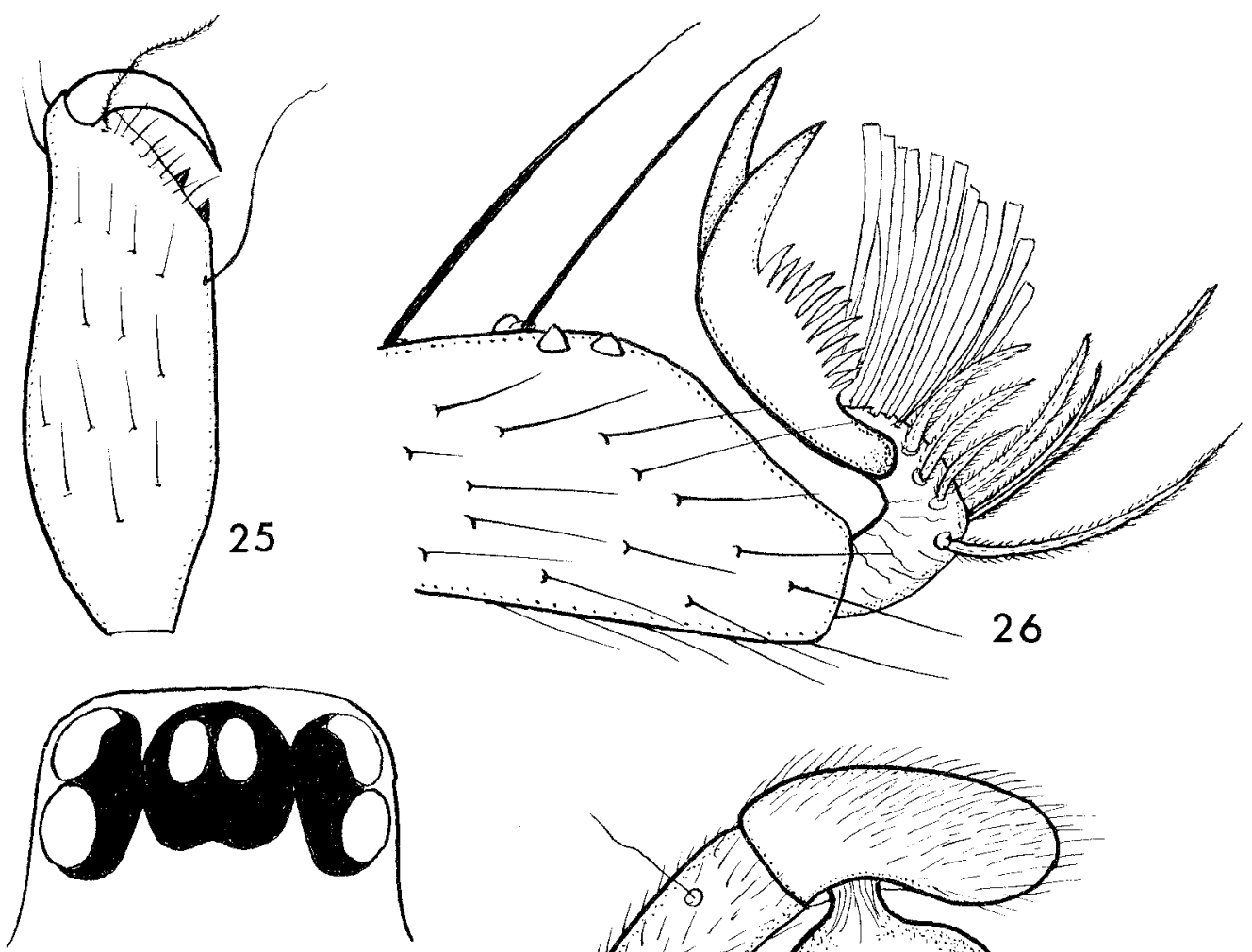

24
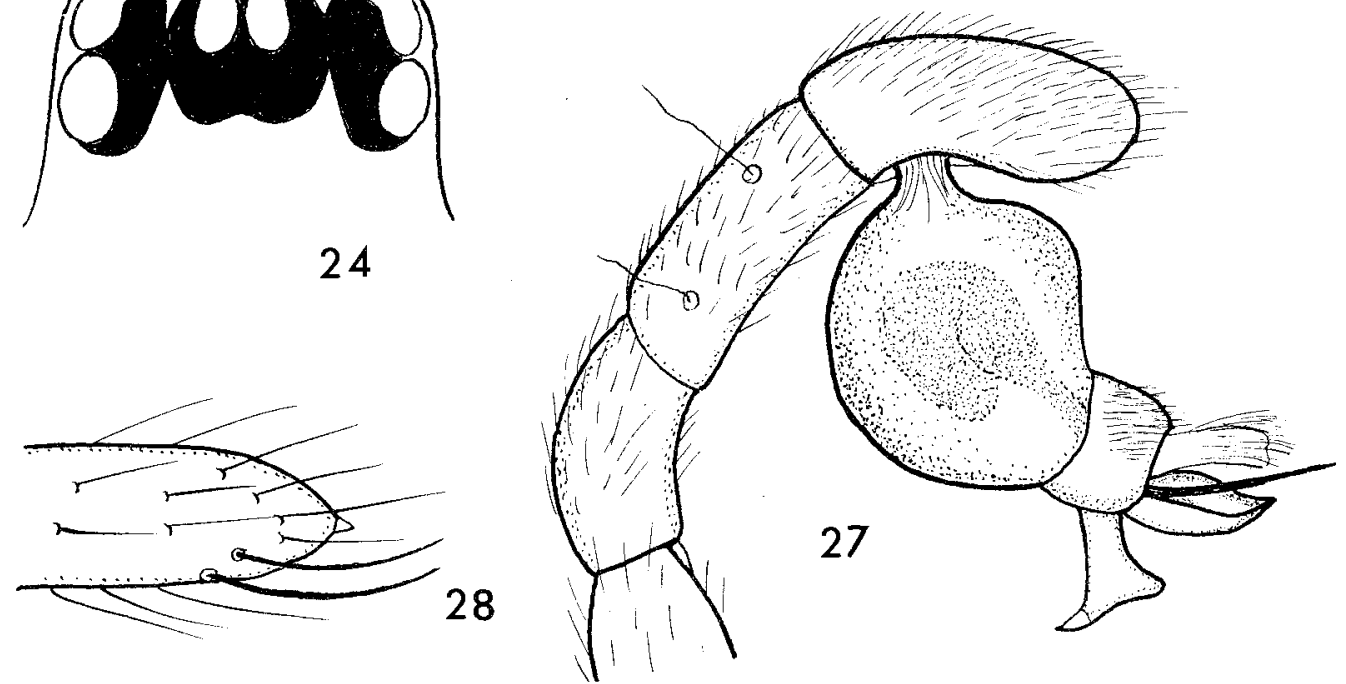

FIGS 24-28.- Tasmanoonops magnus sp. n. Male: 24-eyes, 25-prolateral side of 1 eft chelicera, 26-tarsal claws, 27-right palp. Female: 28-end of tarsus of palp.

projects from the apex and adjacent to it is a ligule covered with short hairs. On the retrolateral side of the apical division of the bulb a stout apophysis projects.

Abdomen ovoid, nearly twice as long as wide, covered with short hairs. Lung-slits and tracheal spiracles are in the usual position on the venter. Six spinnerets, the hind pair projecting beyond the others. Colulus with a number of setae is present. 
projects from the apex and adjacent to it is a ligule covered with short hairs. On the retrolateral side of the apical division of the bulb a stout apophysis projects.

Abdomen ovoic, nearly twice as long as wide, covered with short hairs. Lungslits and tracheal spiracles are in the usual position on the venter. Six spinnerets, the hind pair projecting beyond the others. Colulus with a number of setae is present.

Female

Measurements in ma:-

$\begin{array}{ll}\text { Body length } & 4.28 \\ \text { Carapace length } & 1.83 \\ \text { Carapace width } & 1.54 \\ \text { Abdomen length } & 2.40 \\ \text { Abdomen width } & 1.66\end{array}$

$\begin{array}{crcccrr}\text { Leg } & \text { Femur } & \text { Pate11a } & \text { Tibia } & \text { Metatarsus } & \text { Tarsus } & \text { Tota1 } \\ 1 & 2.00 & 0.80 & 1.71 & 1.66 & 0.63 & 6.80 \\ 2 & 1.94 & 0.86 & 1.71 & 1.66 & 0.68 & 6.85 \\ 3 & 1.60 & 0.57 & 1.14 & 1.26 & 0.57 & 5.14 \\ 4 & 2.29 & 0.63 & 1.60 & 2.00 & 0.68 & 7.20 \\ \text { Palp } & 0.63 & 0.29 & 0.34 & - & 0.74 & 2.00\end{array}$

Female resembles male in colour and appearance but has shorter legs. Palp has two trichobothria on tibia. Tarsus ends in a sharp point and has two large curved setae on the ventral side near apex (fig. 28). Anterior spinnerets lack hook-shape spines. Colulus resembles that of male.

Type locality: Western Creek, Tasmania, 1 d (holotype), 1 o (a11otype), 2 o d (paratypes) from moss 21/1/1931; 3 o o (paratypes) from under decaying 1 ogs 29/1/1930 (V.V. Hickman).

\section{Family ANAPIDAE Kratochvil, 1935}

Spiders belonging to this family are less than $2.0 \mathrm{~mm}$ in body 1 ength. They have six or eight eyes in two rows. When present the anterior median eyes are diurnal. Clypeus is high. Chelicerae not fused together, without 1ateral condyles and without teeth on retromargin of furrow. Labium rebordered. Legs with metatarsi much shorter than tarsi. The three tarsal claws are non-pectinate. Accessory claws may be present or lacking. Female palp very small or reduced to a rudiment. Male palp long and with apophyses on one or more of the segments. Paracymbium lacking. Booklungs lacking, respiration by tracheal tubes.

Anapidae occur in moss and litter of rain-forests and sometimes under loose stones in damp situations. Some make orb webs like those of the Argiopidae, others construct irregular webs like those of the Theridiidae. Very little has been recorded concerning the Australian species.

Genus ACROBLEPS gen. n.

\section{Diagnosis}

Carapace high. Eight eyes in a close group. Cephalic region slightly constricted. Carapace high. Chelicerae with two teeth on promargin, none on retromargij. Male palp with tibial apophyses and a coiled embolus. Tarsi more than twice the length of metatarsi. Three tarsal claws. In both sexes abdomen soft without scutes or sclerites. A colulus and six spinnerets present. Book-lungs and posterior tracheal spiracle lacking. A pair of anterior tracheal spiracles 1ead into tracheae that are confined to the abdomen. 
Type of genus: Acrobleps hygrophitus sp. n.

\section{Acrobleps hygrophilus sp. n.}

Male

$\begin{array}{ll}\text { Measurements in mm:- } & \\ \text { Body length } & 1.10 \\ \text { Carapace length } & 0.58 \\ \text { Carapace width } & 0.52 \\ \text { Abdomen length } & 0.81 \\ \text { Abdomen width } & 0.69\end{array}$

\begin{tabular}{|c|c|c|c|c|c|c|}
\hline Leg & Femur & Patella & Tibia & Metatarsus & Tarsus & Total \\
\hline 1 & 0.62 & 0.22 & 0.44 & 0.21 & 0.51 & 2.00 \\
\hline 2 & 0.56 & 0.21 & 0.40 & 0.19 & 0.49 & 1.85 \\
\hline 3 & 0.45 & 0.19 & 0.31 & 0.18 & 0.42 & 1.55 \\
\hline 4 & 0.55 & 0.19 & 0.38 & 0.19 & 0.44 & 1.75 \\
\hline Palp & 0.27 & 0.11 & 0.05 & - & 0.16 & 0.59 \\
\hline
\end{tabular}

Body and appendages greyish brown, ocular region black, sternum dark brown. Carapace slightly longer than wide, high, rounded at the sides, declivous in front and behind. Cephalic part high and slightly constricted below the eyes, projecting forward but not overhanging front margin (fig. 29). Thoracic grooves indistinct. Eight eyes in two rows forming a close group. Viewed from above the front row appears strongly recurved, hind row almost straight. Ratio of eyes AME:ALE:PME:PLE = 3:5:5:5; AME separated from each other and from ALE by $1 / 3$ their diameter. Lateral eyes contiguous. PME separated from each other by $1 / 3$ and from PLE by $2 / 3$ diameter of AME. Median ocular area wider behind than in front in ratio $8: 7$, its length equal to its posterior width. Height of clypeus seven times diameter of AME. Chelicerae conical, vertical, without lateral condyles, clothed with a few long setae in front. Furrow slightly oblique, two large teeth on promargin, none on retromargin (fig. 30), a row of five long barbed hairs behind retromargin. Fang strong and well curved. Maxillae converging in front of labium, clothed with a few long hairs, a scopula at apex and a well developed serrula on front margin. Labium three times wider than long, truncate in front and provided with three long hairs. Sternum convex, shield-shape, truncate behind, widely separating fourth coxae, surface clothed with a few long hairs pointing forward.

Legs in order of length 1.2.4.3.; clothed with long hairs, spines lacking but there is a bristle at the apex of each patella, two dorsal bristles on each tibia; the first tibiae also have a prolateral bristle. Three trichobothria on the tibiae of the first three legs, and four on those of the fourth legs. One trichobothrium on the metatarsi of the first three legs, none on those of the fourth legs. A drum is present near the base of each tarsus. Three tarsal claws without teeth. Accessory claws present.

Palpi about half the length of the body. Cymbium small and spoon-shape. Genital bulb provided with a long embolus coiled in a close spiral of about four turns, the end of the embolus being freely exposed on the retrolateral side of coil (fig. 31). Apex of tibia produced into a long sharp apophysis, which rests against the side of the cymbium, extending slightly beyond the apex. At the base of the tibia on the ventral side is a small tooth-like apophysis. The patella is extended into an apical point, which rests on the dorsal side of the tibia. The palp is flexed so that the coiled embolus rests against the femur, the whole appendage being turned inwards with its prolateral side facing upwards. 

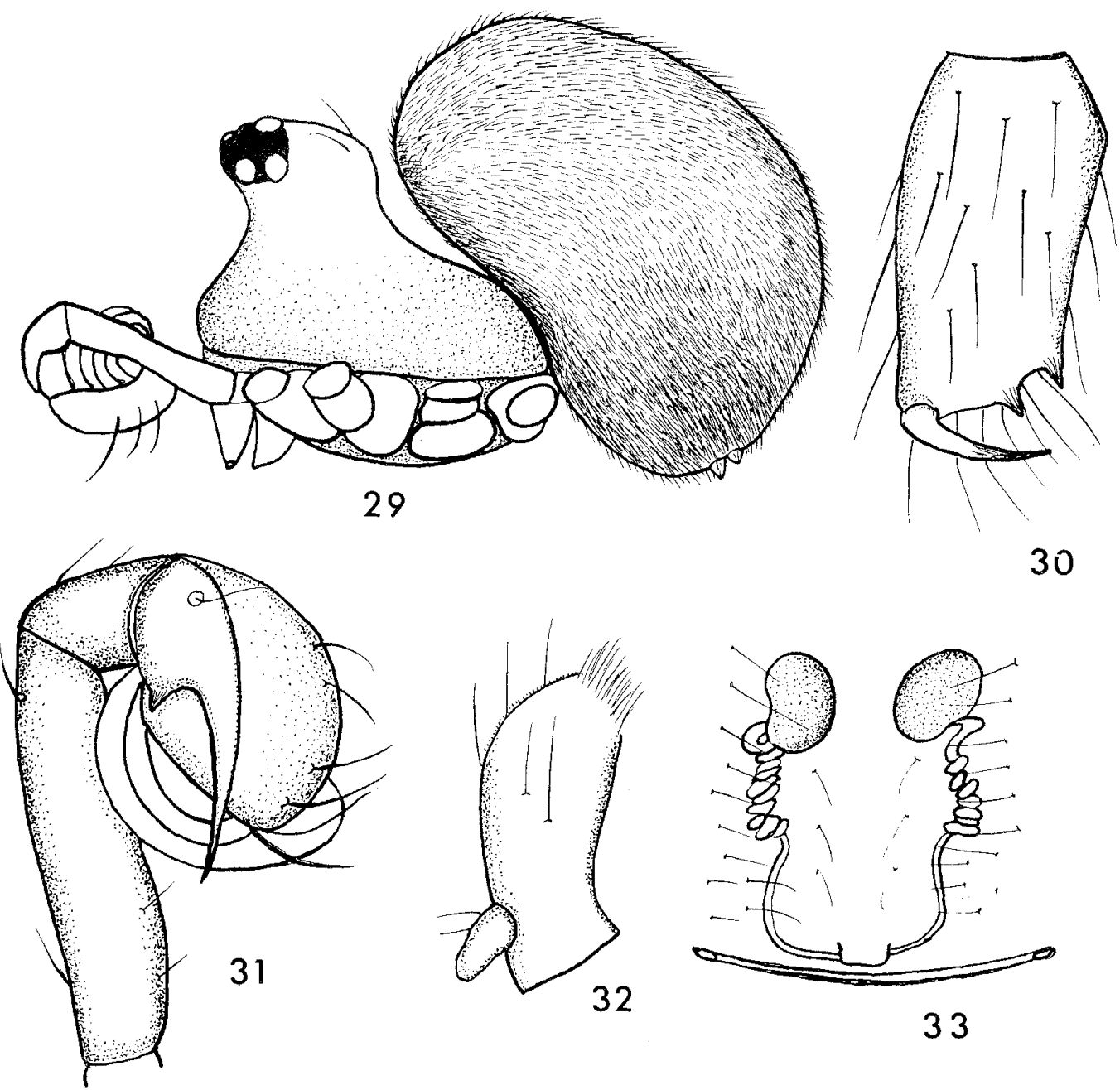

FIGS 29-33.- Acrobleps hygrophizus sp. n. Male: 29-body, 30-prolateral side of right chelicera, 31-right palp. Female: 32-maxillary endite with vestigial pa1p, 33-epigynum in transparent preparation.

Abdomen broadly ovoid, overhanging carapace almost to the head region, thick1y clothed with long hairs, soft without scutes or sclerites. Book-lungs, lung-covers, and posterior tracheal spiracle lacking. A pair of anterior tracheal spiracles are present, one at each end of the epigastric furrow. The tracheal system is confined to 


\section{V.V. Hickman}

the abdomen. Six spinnerets and a colulus are present. The colulus has two setae.

Female

Measurements in mm:-

Body length $\quad 1.45$

Carapace length $\quad 0.64$

Carapace width 0.55

Abdomen length $\quad 1.00$

Abdomen width $\quad 0.93$

$\begin{array}{crccccr}\text { Leg } & \text { Femur } & \text { Pate11a } & \text { Tibia } & \text { Metatarsus } & \text { Tarsus } & \text { Tota } 1 \\ 1 & 0.92 & 0.32 & 0.69 & 0.33 & 0.64 & 2.90 \\ 2 & 0.82 & 0.30 & 0.59 & 0.29 & 0.62 & 2.62 \\ 3 & 0.64 & 0.26 & 0.45 & 0.26 & 0.56 & 2.17 \\ 4 & 0.77 & 0.26 & 0.58 & 0.27 & 0.59 & 2.47\end{array}$

Female resembles the male in colour and general appearance except for the following features: Carapace not as high. Clypeus convex from above down with a distinct groove below the eyes. Palpi vestigial being reduced to a small conical projection on the anterolateral surface of the maxillary endite near the base (fig. 32). Abdomen more globose than in male. The epigynum has the form shown in fig. 33. In transparent preparations the spermathecae appear as a single pair of rounded sacs, each with a spirally coiled duct leading to the external aperture.

Type 1ocality: Myrtle Gu11y, The Cascades, Tasmania, $1 \delta$ (holotype), 1 o (a1lotype), 10 of (paratypes) collected under stones at side of creek 13/12/1945 (V.V. Hickman).

Habits: Acrobleps hygrophilus occurs in moist situations under loose stones on the margins of creeks in fern gullies. It is not unusual to find the spider on the undersurface of a stone below which water is actually flowing, provided the surface is not submerged. The spider spins an orb web, which is suspended horizontally across any convenient depression in the surface of the stone. A specimen of Acrobleps hygrophizus was kept alive in a small specimen tube, the inner surface of which had been moistened with a drop of water. Collembola were provided as food. Under these conditions the spider spun its web in the tube and the web was easily examined under the microscope. It was about $20 \mathrm{~mm}$ in diameter with 11 rays and 30 turns in the viscid spiral. It had a small irregular hub slightly drawn up by a thread from above. No notched zone was constructed. The distance between adjacent turns in the viscid spiral was $0.24 \mathrm{~mm}$. In a length of $1.0 \mathrm{~mm}$ of the viscid thread there were 125 viscid droplets.

Affinities: In spinning an orb web and in the female having reduced palpi, $A$. hygrophitus resembles spiders in the genera Risdonius, Chasmocephaton and Patu. It differs from Risdonius in lacking book-lungs, lung-covers and a posterior tracheal spiracle; from Chasmocephazon and Patu in its tracheal tubes not entering the cephalothorax, and also from Patu in having eight eyes and non-fused chelicerae. Forster (1959) placed the three genera mentioned above in the family symphytognathidae, but in a more recent revision of that family by Forster and Platnick (1977) Risdonius and Chasmocephazon are transferred to the family Anapidae.

Genus OLGANIA gen. n.

Diagnosis

Carapace high, six eyes, cervical groove strongly marked. Patella and tibia of male palp with apophyses, genital bulb with a long embolus. Female palp without claw. Dorsal and epigastric scutes fused together in both sexes investing the greater part of abdomen. Posterior end of abdomen deeply indented in both sexes. Book-1ungs and 

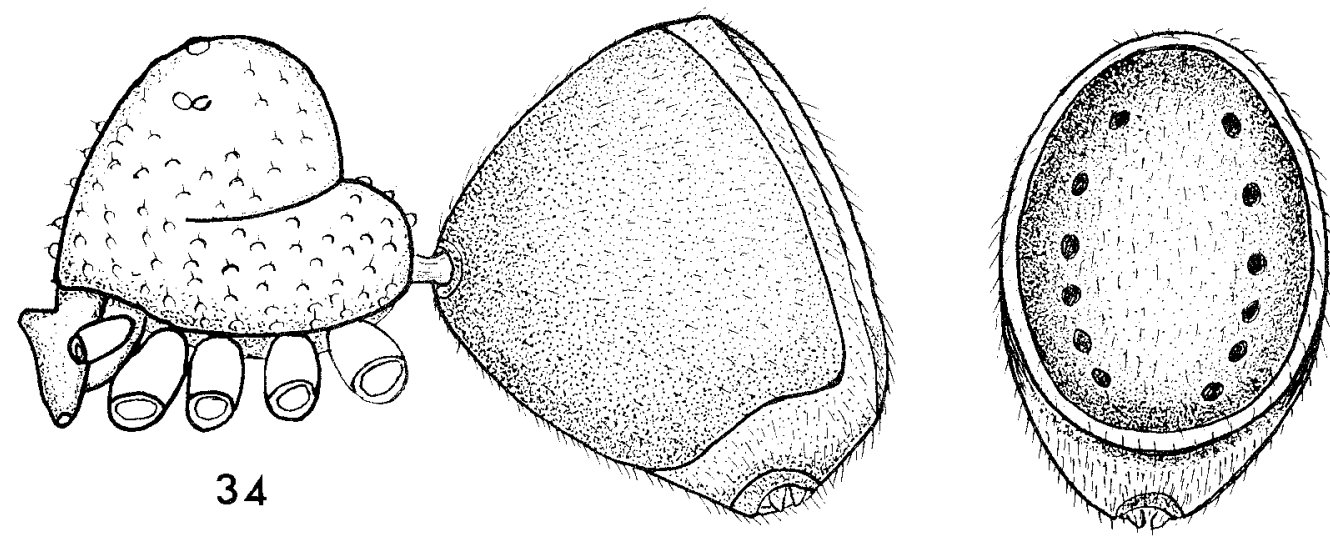

37
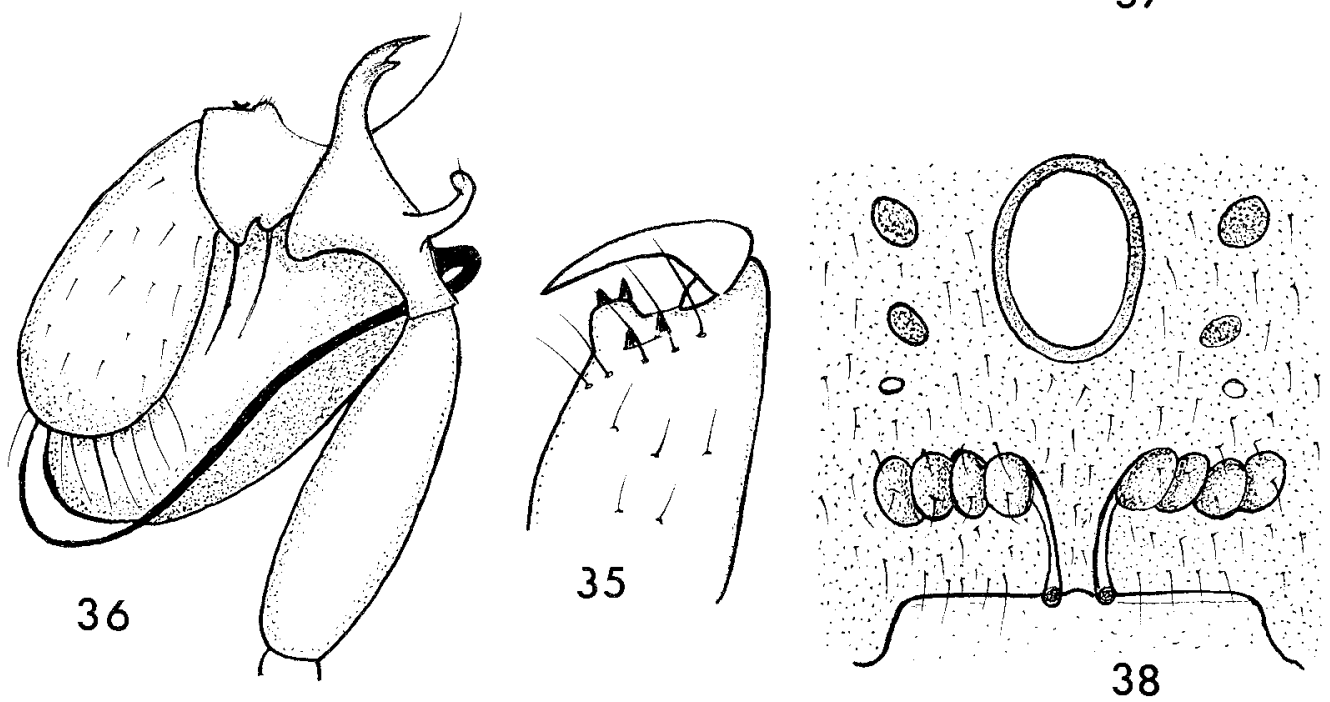

FIGS 34-38. - Olgania excavata sp. n. Ma1e: 34-body, 35-retrolateral side of 1 eft chelicera, 36-1eft palp, 37-hind view of abdomen. Female: 38-epigynum in transparent preparation.

posterior tracheal spiracle absent. A pair of anterior tracheal spiracles open on epigastric scute. Some tracheae enter cephalothorax. Six spinnerets and a colulus surrounded by a sclerotized ring.

Type of genus: Ozgania excavata sp. n. 
Ozgania excavata sp. n.

Ma1e

$\begin{array}{ll}\text { Measurements in mm:- } & \\ \text { Body length } & 0.91 \\ \text { Carapace length } & 0.43 \\ \text { Carapace width } & 0.39 \\ \text { Abdomen length } & 0.50 \\ \text { Abdomen width } & 0.46\end{array}$

$\begin{array}{ccccccr}\text { Leg } & \text { Femur } & \text { Patella } & \text { Tibia } & \text { Metatarsus } & \text { Tarsus } & \text { Tota1 } \\ 1 & 0.53 & 0.11 & 0.42 & 0.20 & 0.32 & 1.58 \\ 2 & 0.47 & 0.11 & 0.40 & 0.17 & 0.32 & 1.47 \\ 3 & 0.46 & 0.10 & 0.31 & 0.17 & 0.29 & 1.33 \\ 4 & 0.53 & 0.11 & 0.45 & 0.20 & 0.34 & 1.63 \\ \text { Palp } & 0.21 & 0.10 & 0.08 & - & 0.15 & 0.53\end{array}$

Cephalothorax and appendages brownish yellow. Sclerotized parts of abdomen light brown, soft parts greyish white.

Carapace (fig. 34) high, sloping steeply to hind margin. Cervical groove strongly marked. Clypeus higher than length of chelicerae and inclined slightly backward. Surface of carapace with numerous tubercles, each with a small seta. Six eyes, a median pair and two 1ateral pairs. Median pair separated from each other by half their diameter and from the laterals by four times that distance. Laterals contiguous. A11 the eyes about equal in size.

Chelicerae vertical, without lateral condyles. In front near the base a low apophysis directed mesad. Fang well curved. Dentition difficult to see but appears to be like that of female (fig. 35). Maxillae strongly converging over front of labium and provided with a small scopula at the apex and a serrula on front margin. Labium longer than wide, pointed in front and partly concealed by the converging maxillae. Sternum slightly wider in front than long, rounded at the sides, truncate behind widely separating the fourth coxae. Margin rebordered and extended upward forming a series of condyloid cavities into which the bases of the coxae fit. Surface of sternum convex, clothed with a few short setae interspersed with low tubercles.

Legs in order of length 4.1.2.3. A bristle at the apex of each patella and two on each tibia. Two trichobothria on first tibiae, three on second and third, four on the fourth. One trichobothrium on each metatarsus except the fourth, which has none. A drum near the base of each tarsus. Three tarsal claws; no accessory claws.

Palpi have two large apophyses on patella, the more basal one curved downward with a seta at its free end, the distal one larger, curved upward, with a forked apex. The tibia has a small setigerous tubercle on the retrolateral side and two larger tubercles on the prolateral side, each with a long seta extending over the genital bulb. Cymbium small with a fringe of long hairs at the apex. Embolus long, slender, arising near base of bulb it passes round the bulb and the apex of the cymbium to end slightly beyond the forked apophysis on the patella (fig. 36).

The abdomen has a strongly sclerotized investment surrounding the anterior two thirds (fig. 34). This appears to be formed by the fusion of a large dorsal scute with the epigastric scute. The posterior third of the abdomen is deeply indented forming a cavity, which has a row of six small sclerites on each side (fig. 37). The surface of the abdomen is clothed with short hairs, those on the dorsum and sides each arising from sclerotized base. The six spinnerets and colulus are surrounded by a 
large sclerotized ring. Book-lungs and posterior tracheal spiracle are lacking. A pair of anterior tracheal spiracles open on the epigastric scute. Some tracheae enter the cephalothorax.

Female

$\begin{array}{ll}\text { Measurements in mm:- } & \\ \text { Body length } & 0.92 \\ \text { Carapace length } & 0.42 \\ \text { Carapace width } & 0.36 \\ \text { Abdomen length } & 0.50 \\ \text { Abdomen width } & 0.49\end{array}$

$\begin{array}{ccccccr}\text { Leg } & \text { Femur } & \text { Pate11a } & \text { Tibia } & \text { Metatarsus } & \text { Tarsus } & \text { Total } \\ 1 & 0.49 & 0.10 & 0.39 & 0.17 & 0.35 & 1.50 \\ 2 & 0.39 & 0.10 & 0.35 & 0.15 & 0.32 & 1.31 \\ 3 & 0.35 & 0.08 & 0.25 & 0.14 & 0.29 & 1.11 \\ 4 & 0.42 & 0.11 & 0.40 & 0.17 & 0.33 & 1.43 \\ \text { Palp } & 0.12 & 0.04 & 0.07 & - & 0.08 & 0.31\end{array}$

Female resembles the male in colour and form with a similar sclerotization and deep indentation of the abdomen. Carapace, however, is not so high. Tarsi with a drum and lacking a claw.

Epigynum (fig. 38) has the form of two short median grooves leading to a pair of small rounded projections at middle of epigastric furrow. Below the projections are the apertures of the ducts leading to the spermathecae. The latter appear through the integument as a pair of large convoluted tubes or sacs extending laterally beyond the ends of the epigastric furrow.

Type 1ocality: Southwestern Tasmania, Gordon River Valley, $145^{\circ} 44.5^{\prime} \mathrm{E}, 42^{\circ} 35.5^{\prime} \mathrm{S}$, 1 of (holotype) from moss 4/2/1976 (C. Howard et al.) ; $145^{\circ} 49^{\prime} \mathrm{E}, 42^{\circ} 43.2^{\prime} \mathrm{S}, 1$ o (allotype) from moss about $1.5 \mathrm{~km}$ west of junction of Gordon and Denison Rivers, 16/2/1978 (L. Hil1 et a. ) ; $145^{\circ} 50^{\prime} \mathrm{E}, 42^{\circ} 43^{\prime} \mathrm{S}, 1$ o (paratype) from moss in the same area (L. Hill et al.).

\section{Family MYSMENIDAE}

Petrunkevitch (1928) established the Mysmeninae as a sub-family of the Theridiidae. Gertsch (1960) transferred it to the Symphytognathidae. Forster and Platnick (1977) raised it to rank as a family, the Mysmenidae. The chief characters of the family are as follows:-

Small spiders, mostly $1.0-3.0 \mathrm{~mm}$ in length. Carapace high. Abdomen soft without scutes. Eyes eight. Tarsi longer than or equal to the metatarsi. Three tarsal claws without teeth. No comb on fourth tarsi. Female palp not vestigial but lacking a claw. Male usually with a clasping spine on first metatarsi. A colulus and six spinnerets present. Apneumone or with book-1ungs.

Little is known concerning the habits of these minute spiders. Some are recorded as spinning irregular webs (Gertsch 1960).

Genus MYSMENA Simon, 1894

Mysmena tasmaniae sp. n.

Male

$\begin{array}{ll}\text { Measurements in mm:- } & \\ \text { Body 1ength } & 0.75 \\ \text { Carapace length } & 0.41\end{array}$


V.V. Hickman

$\begin{array}{ll}\text { Carapace width } & 0.33 \\ \text { Abdomen length } & 0.57 \\ \text { Abdomen width } & 0.45\end{array}$

$\begin{array}{ccccccr}\text { Leg } & \text { Femur } & \text { Patella } & \text { Tibia } & \text { Metatarsus } & \text { Tarsus } & \text { Total } \\ 1 & 0.31 & 0.12 & 0.26 & 0.16 & 0.20 & 1.05 \\ 2 & 0.26 & 0.11 & 0.22 & 0.15 & 0.19 & 0.93 \\ 3 & 0.20 & 0.10 & 0.14 & 0.14 & 0.18 & 0.76 \\ 4 & 0.27 & 0.11 & 0.19 & 0.15 & 0.19 & 0.91 \\ \mathrm{~Pa} 1 \mathrm{p} & 0.20 & 0.07 & 0.07 & - & 0.14 & 0.48\end{array}$

Carapace dark brown on head region, paler posteriorly and at the sides. Sternum with dark marks on each side. Legs yellow with dark rings. Abdomen almost black with four large white spots on dorsum, and two smaller ones on each side. A white area above the spinnerets extends partly onto the sides and ventral surface (fig. 39). Head region high and slightly overhanging clypeus. Eight eyes in two transverse rows; hind row almost straight, front row procurved. Eye ratio AME:ALE:PME:PLE $=13: 12: 15: 12$. AME separated from each other by $17 / 13$ of their diameter and almost touching ALE. PME separated from each other by $1 / 13$ of their diameter and from PLE by the same distance. Height of clypeus $7 / 3$ diameter of AME.

Chelicerae (figs 40 and 41 ) $0.18 \mathrm{~mm}$ long and $0.07 \mathrm{~mm}$ wide, conical, vertical, without lateral condyles; a smal1 apophysis and stridulating ridges on mesal side. Furrow oblique with three large teeth on promargin and a group of small teeth behind them in the furrow. Maxillae strongly converging over labium, with a small scopula at apex and a serrula on front margin. Labium triangular and as 1 ong as wide. Sternum shie1d-shape, slightly longer than its anterior width, truncate behind separating the fourth coxae by almost twice their diameter.

Legs in order of length 1.2.4.3., the second and fourth pairs almost equal. A stout, curved prolateral spine on the distal third of the first metatarsus (fig. 42). Two trichobothria on first and second tibiae, three on third and fourth, but some variation occurs in different specimens. One trichobothrium on each metatarsus except the fourth, which has none. A small sclerotized spot on the ventral side of the first and second femora about $1 / 3$ from distal end (fig. 43). Tarsus has a drum almost at the junction with metatarsus, three pectinate claws but no accessory claws.

Palpi have a relatively long femur equal to that of the third pair of legs. No apophyses occur on any of the segments. The cymbium has a short hook-like spine near the apex. Embolus long and slender; it arises from the surface of the genital bulb and makes a complete turn round the bulb ending near the apex of the cymbium (fig. 44).

Abdomen rounded without a cauda1 hump, clothed with short simple setae. Booklungs, lung covers and posterior tracheal spiracle lacking. A pair of anterior tracheal spiracles are situated one at each end of the epigastric furrow. A number of tracheal tubes enter the cephalothorax. Six spinnerets and a colulus are present.

Female

Measurements in $\mathrm{mm}:-$

Body 1 ength

0.97

Carapace length

Carapace width

0.39

Abdomen width $\quad 0.58$ 


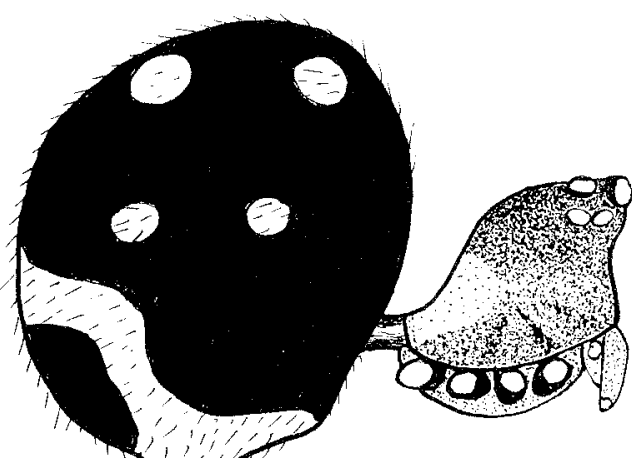

39
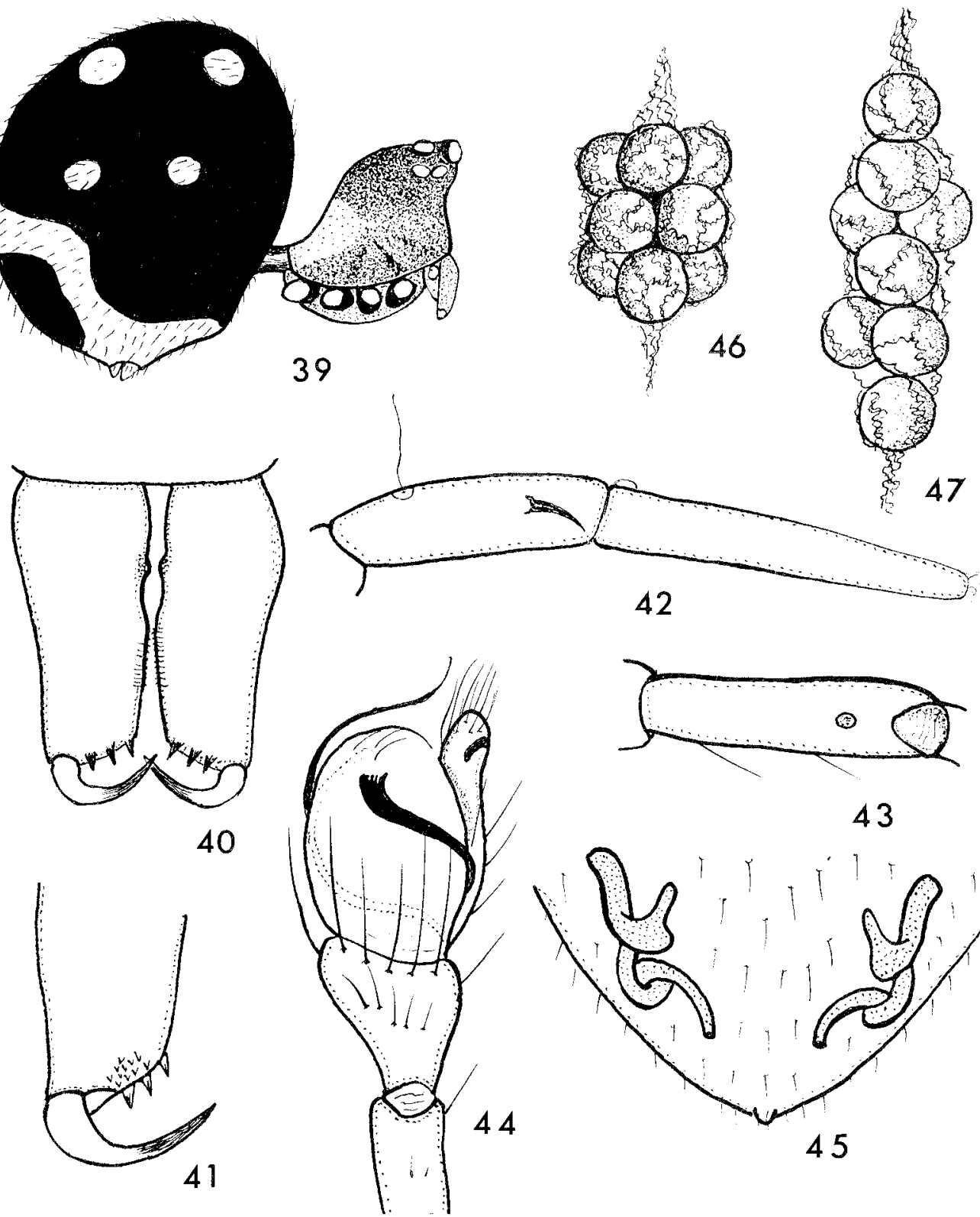

43

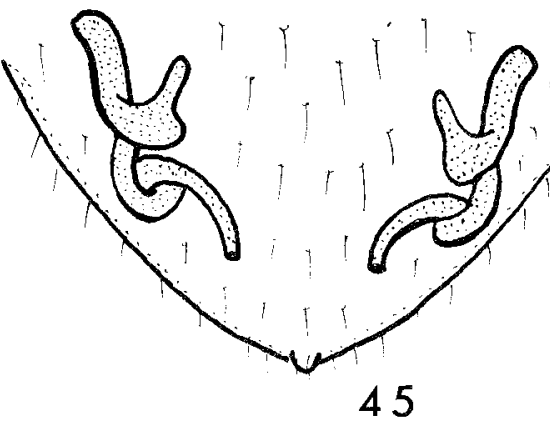

FIGS 39-47.- Mysmena tasmaniae sp. n. Male: 39-body, 40-prolateral view of chelicerae, 41-retrolateral side of left chelicerae, 42-metatarsus and tarsus of first leg, 43ventral side of first femur showing sclerotized spot, 44-right palp. Female: 45epigynum in transparent preparation, 46-egg-mass as laid, 47-egg-mass extended. 


$\begin{array}{ccccccr}\text { Leg } & \text { Femur } & \text { Patella } & \text { Tibia } & \text { Metatarsus } & \text { Tarsus } & \text { Total } \\ 1 & 0.33 & 0.14 & 0.23 & 0.18 & 0.19 & 1.07 \\ 2 & 0.27 & 0.11 & 0.20 & 0.15 & 0.19 & 0.92 \\ 3 & 0.20 & 0.11 & 0.16 & 0.12 & 0.16 & 0.75 \\ 4 & 0.30 & 0.12 & 0.20 & 0.16 & 0.19 & 0.97 \\ \text { Palp } & 0.12 & 0.05 & 0.07 & - & 0.12 & 0.36\end{array}$

Female is slightly larger than the male, but has the same colouration, markings and general features. However, the carapace is not as high, chelicerae shorter, without stridulating ridges or apophysis on mesal side. Female has no claw on palp and also lacks a clasping spine on the first metatarsus. Epigynum a triangular lobe ending in a small knob-like scape (fig. 45). Spermathecae have the form of a pair of twisted tubes, when seen in transparent preparations.

Type locality: Maxwell River Valley, Southwestern Tasmania, $145^{\circ} 55^{\prime} \mathrm{E}, 42^{\circ} 38^{\prime} \mathrm{S}$, $10^{\circ}$ (holotype); $145^{\circ} 54^{\prime} \mathrm{E}, 42^{\circ} 38^{\circ} \mathrm{S}, 1$ o (a1lotype) from leaf 1 itter $5 / 1 / 1978$ (L. Hill et al.).

Other localities: Tarraleah, Tasmania, 1 f from moss 11/5/1953 (V.V. Hickman); East Risdon, Tasmania, 1 o from grass tussocks 23/9/1975 (V.V. Hickman); various va1leys in southwestern Tasmania, 12 of , 25 oo from moss and forest 1itter, January, February and March, 1976, 1977 and 1978 (C. Howard, L. Hil1 et al.).

Affinities: Mysmena tasmaniae has a strong resemblance to the American species Mysmena increduza (Gertsch and Davis). It differs in the form of the spermathecae, in having a hooked spine on the cymbium of the male and to a lesser degree in abdominal markings.

Habits and 1ife cycle: Under labofatory conditions Mysmena tasmaniae spun a small web amongst some grass-sta1ks. The web was formed of a few irregular threads, most of which were in a horizontal plane. The spider rested below the web the threads of which were not viscid and did not ensnare prey. Smal1 Collembola were provided as food. If one of these disturbed a thread of the web, the spider rushed to the spot and caught the insect. The prey was not wrapped up in threads, but killed and suspended in the web until required.

Breeding occurs during spring and summer. In mating the male approaches the female and takes up a position immediately in front of her, extending his left palp across her sternum. The long femur of the palp enables the epigynum to be reached from in front of the female. The act of copulation was observed under the microscope. The male first employed his left palp, inserting the embolus in the right spermathecal aperture of the female. It was soon withdrawn and again inserted. This occurred about eight times in five minutes. The male then applied his right palp to the left spermathecal aperture of the female in a similar manner. After copulation the male retired to the outer parts of the web and moved about actively, occasionally stopping to pluck the threads and to draw his first and second tarsi between his chelicerae. Meanwhile the female remained below the web and also often plucked the threads. If the male approached a second time, the female plucked the threads more rapid1y and he retired. Eggs were laid three days after mating.

The eggs, eight to twelve in number, measure $0.35 \mathrm{~mm}$ in diameter and are yellowish in colour. They are not enclosed in an egg-sac or capsule (fig. 46), but are held together in a mass by a few crinkled threads. Under laboratory conditions one female laid six lots of eggs during the period 25 october 1975 to 9 January 1976. The egg mass is suspended below the web, and when the eggs are first laid, the mass measures $1.15 \mathrm{~mm}$ long and $0.74 \mathrm{~mm}$ in greatest width. However, the spider, which rests 
below the eggs, sometimes pulls on the enveloping threads, loosening the eggs and thus causing the mass to elongate to $2.4 \mathrm{~mm}$ (fig. 47).

Incubation lasts 10-15 days and after hatching the spider passes through two to four instars before reaching maturity. The first postembryonic instar appears to occur within the egg and its duration is not shown separately in Table 1, but is included in the duration of incubation. On hatching the instar that escapes from the ruptured chorion has the features of a normal second postembryonic stage - thus it is clothed with setae, has three tarsal claws, moves actively and is able to spin. As is shown in Table 1 there is considerable variation in the duration of the juvenile instars. The total time from egg-laying to maturity is $29-52$ days. This very short life cycle makes it possible for at least three generations to be passed through in the one summer.

\section{TABLE 1}

Mysmena tasmaniae sp. $\mathrm{n}$. Duration (in days) of incubation and juvenile instars of ten specimens $(\mathrm{A}-\mathrm{J})$ bred in the laboratory

\begin{tabular}{|c|c|c|c|c|c|c|c|c|}
\hline & $\begin{array}{l}\text { Egg } \\
\text { laid }\end{array}$ & $\begin{array}{l}\text { Incub- } \\
\text { ation }\end{array}$ & $\begin{array}{c}\text { Instar } \\
\text { II }\end{array}$ & $\begin{array}{l}\text { Instar } \\
\text { III }\end{array}$ & $\begin{array}{c}\text { Instar } \\
\text { IV }\end{array}$ & $\underset{V}{\text { Instar }}$ & Tota1 & Sex \\
\hline & 1975 & & & & & & & \\
\hline A & 25 oct. & 15 & 16 & 11 & 6 & - & 48 & $\stackrel{\circ}{+}$ \\
\hline B & 25 oct. & 15 & 17 & 1.2 & 8 & - & 52 & o \\
\hline $\mathrm{C}$ & 25 Oct. & 15 & 21 & 8 & 7 & - & 51 & 0 \\
\hline D & 15 Nov. & 12 & 4 & 11 & 6 & 8 & 41 & $\stackrel{p}{+}$ \\
\hline E & 29 Nov. & 9 & 18 & 9 & 8 & - & 44 & 0 \\
\hline $\mathrm{F}$ & 29 Nov. & 9 & 22 & 9 & - & - & 40 & $\stackrel{0}{+}$ \\
\hline G & 28 Dec. & 10 & 10 & 5 & 8 & - & 33 & q \\
\hline $\mathrm{H}$ & $28 \mathrm{Dec}$. & 10 & 10 & 3 & 6 & - & 29 & o \\
\hline I & $28 \mathrm{Dec}$ & 10 & 10 & 10 & 14 & - & 44 & $\stackrel{0}{+}$ \\
\hline $\mathrm{J}$ & 28 Dec. & 10 & 20 & 2 & 14 & - & 46 & q \\
\hline
\end{tabular}

The type specimens of new species described in this paper will be lodged in the Australian Museum, Sydney, and paratypes, where available, in the Tasmanian Museum and Art Gallery, Hobart. The allotype of oonopinus mozlipes will be lodged in the Queen Victoria Museum, Launceston, where the holotype was deposited in 1932 .

\section{REFERENCES}

Forster, R. R., 1959: The spiders of the family symphytognathidae. Trans. R. Soc. N.2., 86: 269-329, figs $1-158$.

and Platnick, N.I., 1977: A review of the spider family symphytognathidae. Amer. Mus. Novitates, 2619, 1-29, figs 1-74.

Gertsch, W.J., 1960: Descriptions of American spiders of the family Symphytognathidae. Amer. Mus. Novitates, 1981, 1-40, figs 1-72.

Hickman, V.V., 1930: Studies in Tasmanian spiders, Part IV. Fap. Proc. R. Soc. Tasm. (1929): 87-122, pl. 19-26.

1932: Studies in Tasmanian spiders, Part $V$ (The oonopidae). Pap. Proc. R. Soc. Tasm. (1931): 2031, figs 1-11. 


\section{V.V. Hickman}

Kratochvil, J., 1935: Araignees cavernicoles de Krivosije. Prace. Morav. prirod. spol., $9(12):$ 1-25, figs 1-21.

Petrunkevitch, A., 1928: Systema Aranearum. Trans. Connecticut Acad. Arts. Soi., $29: 1-270$.

Simon, E., 1893: Arachnides in Voyage de M.E. Simon au Venezuela (Decembre 1887 Avril 1888) $21^{\mathrm{e}}$. Memoire. Ann. Soc. Ent. Fr., 61: 423-462, pl. 9. , 1894: Histoire naturelle des araignées, I (3): Paris, 1894, 489-760, figs $491-837$.

Templeton, R., 1835: On the spiders of the genus Dysdera Latr. with the description of a new allied genus. ZooZ. J., 5: 100-108, pl. 17. 